CAMILA XAVIER DE CARVALHO

ANÁLISE DE TRANSCRIPTOMA POST-MORTEM DE CÉREBRO DE MUS musculus SUBMETIDOS AOS DIFERENTES TIPOS DE EUTANÁSIA PRECONIZADOS PELA COMISSÃO DE ETICA NO USO ANIMAL 


\author{
UNIVERSIDADE DE BRASÍLIA \\ FACULDADE DE CIÊNCIAS DA SAÚDE \\ PROGRAMA DE PÓS-GRADUAÇÃO EM CIÊNCIAS DA SAÚDE
}

CAMILA XAVIER DE CARVALHO

\title{
ANÁLISE DE TRANSCRIPTOMA POST-MORTEM DE CÉREBRO DE MUS musculus SUBMETIDOS AOS DIFERENTES TIPOS DE EUTANÁSIA PRECONIZADOS PELA COMISSÃO DE ÉTICA NO USO ANIMAL
}

Tese apresentada como requisito parcial para a obtenção do Título de Doutor em Ciências da Saúde pelo Programa de Pós-Graduação em Ciências da Saúde da Universidade de Brasília.

Orientadora: Dra. Silviene Fabiana de Oliveira

Co-Orientadora: Dra. Aline Pic-Taylor

Brasília, 2017 


\title{
ANÁLISE DE TRANSCRIPTOMA POST-MORTEM DE CÉREBRO DE MUS musculus SUBMETIDOS AOS DIFERENTES TIPOS DE EUTANÁSIA PRECONIZADOS PELA COMISSÃO DE ÉTICA NO USO ANIMAL
}

Tese apresentada como requisito parcial para a obtenção do Título de Doutor em Ciências da Saúde pelo Programa de Pós-Graduação em Ciências da Saúde da Universidade de Brasília.

Aprovado em

\author{
BANCA EXAMINADORA \\ Prof ${ }^{a}$. Dra ${ }^{\mathrm{a}}$. Silviene Fabiana de Oliveira - (Presidente) \\ Universidade de Brasília - IB - Deptํㅡenética e Morfologia \\ Prof $^{a}$ Dr $^{a}$ Juliana Forte Mazzeu de Araújo \\ Universidade de Brasília - Faculdade de Medicina \\ Prof $^{\mathrm{a}} \mathrm{Dr}^{\mathrm{a}}$ Daniela de Melo e Silva \\ Universidade Federal de Goiás - ICB - Deptō Genética \\ Prof ${ }^{\text {. }}$. Dr ${ }^{\text {a }}$. Rosângela Vieira de Andrade \\ Universidade Católica de Brasília - PRPGP \\ Prof $^{a}{ }^{-a}{ }^{\underline{a}}$ Daniela Mara de Oliveira \\ Universidade de Brasília - IB - Dept ${ }^{\circ}$ Genética e Morfologia \\ Prof ${ }^{a} \mathrm{Dr}^{\mathrm{a}}$ Maria de Nazare Klautau Guimarães \\ Universidade de Brasília - IB - Dept ${ }^{\circ}$ Genética e Morfologia \\ (Suplente)
}

Brasília, 2017 


\section{DEDICATÓRIA}

Ao meu filho Vinicius (in memoriam)

e ao meu esposo Eduardo Junqueira Khouri 


\section{AGRADECIMENTOS}

Agradeço a Deus pela oportunidade da vida.

Aos meus pais e ao meu esposo Eduardo pela força e apoio.

E minha orientadora, Silviene Fabiana de Oliveira e co-orientadora Aline PicTaylor, pela compreensão de todos os momentos difíceis que passei e que tive por ajuda e amizade de vocês.

Aos meus colegas e amigos de jornada acadêmica, Mariana, Rafaela, Sabrina, Marcella, Harumy, Diana, Tatiana, Arthur, Halinna e Ana Carolina pela amizade e carinho prestados a mim e minha família no momento de luto e tristeza pelo qual passamos.

Aos meus colegas Raphael Severino Bonadio, Muriel Lopes e Larissa Nunes pelo apoio técnico.

E meu agradecimento e reconhecimento ao Centro de Apoio a Pesquisa CAPES e ao Dr. Rolando André Villacis, Dr. José Jivago e Prof. Dr. Sacha Braun.

A todos os professores, funcionários, técnicos, alunos, amigos e família que direta ou indiretamente contribuíram para a efetivação desse projeto. 
$A$ verdade não está com os homens,

mas entre os homens.

Sócrates 


\section{RESUMO}

Eutanásia significa morte sem dor ou sem sofrimento, existem diversas técnicas preconizadas para tal objetivo. A eutanásia em animais tem seus procedimentos regulamentados pela resolução do Conselho Federal de Medicina Veterinária (CFMV) e CONCEA/2015. A experimentação animal tem grande importância nas pesquisas científicas, contribuindo para o desenvolvimento da ciência e da tecnologia. Animais de várias espécies são utilizados como cobaias, sendo os camundongos os mais utilizados e os mais conhecidos cientificamente. $O$ método de eutanásia em um estudo in vivo é uma importante escolha e deve seguir as orientações das associações internacionais que regulamentam a eutanásia como uma morte humanitária. A escolha de um método de eutanásia está relacionada à facilidade do método, seu baixo custo, eficácia, disponibilidade e baixo risco ao manipulador. Porém, todas estas qualidades não comprovam que o método de escolha seja o que menos causa sofrimento ao modelo experimental. O estudo comparou o transcriptoma de cérebro de Mus musculus postmortem. Para tanto realizou-se cinco diferentes metodologias de eutanásia: deslocamento cervical, guilhotina, overdose de xilazina/quetamina, overdose de tiopental e câmara $\mathrm{CO}^{2} \mathrm{em}$ camundongos C57BL/6J. Os animais foram divididos em grupos de quatro individuos e seus cérebros foram coletados e destes extraídos o RNA total e realizou-se array de expressão com o GeneChip ${ }^{\circledR}$ MoGene 2.0 ST Array Affymetrix (Santa Clara, CA, EUA). As análises mostram 4.780 genes diferencialmente expressos no tecido cerebral para todos os tipos de morte e, entre estes, 65 descritos na literatura como gene expressos em situação de dor (PainGenesdb). Destes, quatro - Gfra2, Glra2, Grasp e Stoml3 - apresentaram diferenças significativas quando as metodologias foram comparadas par a par. Os métodos físicos (guilhotina e deslocamento cervical) apresentaram menores tempos de $\mathrm{IMCO}, \mathrm{CO}_{2}$ tempo intermediário e xilazina/quetamina o maior desvio padrão para tempo de morte. Conclui-se com este estudo que a eutanásia com deslocamento cervical foi método com melhor reprodutibilidade seguida da decapitação por guilhotina e que as metodologias de eutanásia estudada são similares desde que bem executadas.

Palavras-chaves: expressão gênica, RNA post-mortem, transcriptoma, análise de microarray 


\section{LISTA DE FIGURAS}

Figura 1: Esquema da Nocicepção - Caminho da Dor

Figura 2: Dendrograma construido a partir dos 4.780 genes diferencialmente expressos entre os cinco grupos de eutanásia (1-CO2; 2-DESL; 3-GUIL; 4-TIO e 5$\mathrm{XK})$. As diferenças relativas de expressão gênica são proporcionais a intensidade da coloração (heatmap), sen Erro! Indicador não definido.

Figura 3: Número de genes expressos diferencialmente considerando a comparação para a par entre os diferentes grupos experimentais. 


\section{LISTA DE TABELAS}

Tabela 1:Concentração e RIN das amostras de tecido cerebral utilizadas no atual estudo

Tabela 2: Tempo de morte entre os indivíduos de cada grupo experimental em segundos

Tabela 3: : Comparação dos grupos de eutanásia com relação a expressão de transcritos de genes de dor ( $p<0,05$ e Fold Change Linear $<2$ ou Fold Change $>-2)$

Tabela 4: Genes de dor diferencialmente expressos nas condições de eutanásia testadas. As informações constantes na tabela foram retiradas do banco de dados PAINGENESdb .35

Tabela 5: Genes expressos diferencialmente entre os cinco grupos experimentais, par a par, considerando vias metabólicas (KEGG Pathways)Erro! Indicador não definido. 


\section{LISTA DE ABREVIATURAS}

ACLAM - American College Laboratiral Animal Medicine/Colégio Americano de Medicina Laboratorial Animal

AVMA - American Veterinary Medicine Association/Associação Americana de Medicina Veterinária cDNA - Complementary DNA/DNA complementar

CEUA - Comissão de Ética no Uso de Animais

CEUA - Comissão de Ética no Uso de Animais

CFMV - Conselho Federal de Medicina Veterinária

CONCEA - Conselho acional de Controle e Experimentação Animal

cRNA - Complementary RNA/ RNA Complementar

DNA - Desoxiribonucleic acid/ Ácido Desoxirribonucleico

EX - Expression Console

FESBE - Federação Nacional das Sociedades de Biologia Experimental

IB - Instituto de Ciências Biológicas

IMCO - Instalação da morte e a consumação do óbito

mRNA - Messenger RNA/ RNA mensageiro

Qrt-PCR - Quantitative reverse transcriptase-polymerase chain reaction

RIN - RNA intregrity number/ Número de integridade do RNA

RNA - Ribonucleic acid/ Ácido Ribonucleico

ss-cDNA - Single strand CDNA Complementary DNA

SPBC - Sociedade Brasileira para o Progresso da Ciência

TAC - Transcriptome Analysis Console 
1.1 Eutanásia - conceitos e histórico

1.2 Eutanásia em Animais 4

1.3 Eutanásia em Animais de Cativeiro 5

1.4 Eutanásia em Animais Domésticos 7

1.4.1 Animais Domésticos destinados ao Abate 7

$\begin{array}{lll}\text { 1.4.2 Animais de Estimação } & 8\end{array}$

1.5 Eutanásia em Animais de Laboratório 9

1.6 Legislação do uso animal em pesquisa 10

1.7 Métodos de Eutanásia aceitos ou preconizados pela CEUA 13

1.8 Expressão Gênica Post Mortem 17

1.9 Análise de Expressão Gênica 18

$\begin{array}{ll}2 . & 20\end{array}$

3. OBJETIVOS 22

4. METODOLOGIA 23

4.1 Animais 23

4.2 Grupos Experimentais e Preparação do Tecido 24

4.3 Coleta de Tecido Cerebral 26

4.4 Ensaio de Expressão Gênica 26

4.5 Análises de dados de Expressão Gênica em Larga Escala 28

4.6 Análise Funcional em Silico de Genes Diferencialmente expressos $\quad 30$

4.7 Aspectos Éticos 30 
5. RESULTADOS

5.1 Tempo de Morte nos Diferentes Tipos de Eutanásia

5.2 Comparação do Transcriptoma de Cérebro de Camundongo Submetidos aos Diferentes Tipos de Eutanásia

5.3 Comparação Par a Par do Transcriptoma de Cérebro de Camundongo Submetidos aos Diferentes Tipos de Eutanásia

6. DISCUSSÃO

6.1 Intervalo de Tempo Decorrido entre a Instalação da Morte e a Consumação do Óbito

6.2 Transcripitoma de Cérebro de Camundongo e Metodologias de Eutanásia

6.3 Genes Vinculados ao Processo de Dor e Metodologias de Euitanásia 42

6.4 Avaliação in silico de Genes Vinculados ao Processo de Dor Diferencialmente Expressos

7. CONCLUSÕES

8. REFERÊNCIAS

9. ANEXOS 


\section{INTRODUÇÃO}

\subsection{EUTANÁSIA E DOR - CONCEITOS}

Eutanásia significa morte sem dor ou sem sofrimento (do grego euthanasia - a morte bela ou feliz) e existem diversas técnicas preconizadas para tal objetivo. Segundo Pessini (2004), eutanásia em humanos é definida como "a ação de intencionalmente abreviar a vida de um paciente feita por alguém, a pedido explícito deste". Neste último caso, a eutanásia seria justificada como forma de evitar o sofrimento prolongado em decorrência de uma doença (Rocha, 2007).

Na Medicina Veterinária, a eutanásia significa a morte humanitária de um animal por meio de um método que produza inconsciência rápida e subsequente morte sem evidência de dor ou agonia. Ou ainda, um método que utilize drogas anestésicas em doses suficientes para produzir a perda indolor da consciência seguida de parada cardiorrespiratória (IACU, 2002).

A morte é um fenômeno sujeito a múltiplas interpretações, conceituada como término das funções vitais de forma irreversível. É considerado um processo que tem implicações legais, e seu diagnóstico depende de atestar se um indivíduo está vivo ou morto dentro de uma pequena e tolerável margem de incerteza em critérios claros e objetivos, de ampla aceitação social, de modo a garantir confiabilidade (Paizin-Filho, 2005).

A palavra "dor" na língua portuguesa vem do latim: dolore, que significa sofrimento; e "pain" na língua inglesa, do grego: poiné, pena (DeGrazia, 1991). A dor é conceituada como experiência sensorial e emocional desagradável, que está relacionada a lesões reais ou potenciais e que geralmente acompanha a nocicepção (Hellebrekers, 2000). A nocicepção tem relação com os sinais dolorosos reconhecidos pelo sistema nervoso que tem função de relacionar os estímulos com lesão e ocorre mesmo em estado de inconsciência. $O$ componente emocional só pode ser aplicado em seres humanos, porém o termo dor se estende também a animais (Klaumann et al., 2008).

Os animais vertebrados possuem senciência, que é a capacidade de sentir (Luna, 2006; Duncan, 2006), estar consciente de si próprio ou apenas do ambiente que o cerca. Dessa forma, a dor é um importante indicador do estado 
afetivo de um animal, interferindo de forma significativa no seu grau de bemestar (Von Keyserlingk et al., 2009). A confirmação que os animais sentem dor se dá pelo fato que estes evitam ou tentam escapar de estímulos dolorosos (Luna, 2006). A sensação dolorosa pode ser considerada como quinto sinal vital, juntamente com a função cardiorrespiratória e térmica e frequentemente relaciona-se ao sofrimento, estresse e agonia (Holton et al., 2001).

A dor pode ser descrita como uma reação fisiológica ou consequência de uma patologia, uma sensação desagradável que constitui um sistema de defesa do organismo e é condição fundamental para a sobrevivência (Holton et al., 2001; Luna, 2006). Quando fisiológica, a dor, é um alerta sensorial de uma lesão tecidual que leva a mecanismos de defesa ou fuga. Há estímulos que geram lesões ou ferimentos que causam sensação de dor, entre eles o calor, o frio, a pressão, a corrente elétrica, produtos químicos e até mesmo movimentos bruscos (da Silva \& Pinto, 2011).

llustrando a dor como mecanismo de defesa, toma-se como exemplo a anidrose uma doença que causa uma insensibilidade na experiência dolorosa, onde 0 individuo portador pode ter problemas severos de saúde como: automutilações, autoamputações e perda da visão (Carvalho et al., 2014). Já a dor crônica pode surgir em decorrência da falta de tratamento adequado a uma lesão tecidual que acarreta persistência de ativação de vias não relacionadas à mediação de dor em condições normais. Estas vias passam a participar da nocicepção acarretando hiperalgesia e sofrimentos permanentes (Luna, 2006; Holton et al., 2001).

O termo nocicepção é associado ao componente fisiológico da dor, que engloba os processos de transdução, transmissão e modulação de sinais neurais gerados em resposta a um estímulo nocivo externo (Figura 1). Resumidamente, pode-se considerar como uma cadeia de três-neurônios, com o neurônio de primeira ordem originado na periferia e projetando-se para a medula espinhal, o neurônio de segunda ordem ascende pela medula espinhal e o neurônio de terceira ordem projeta-se para o córtex cerebral (Tranquilli, 2004). 


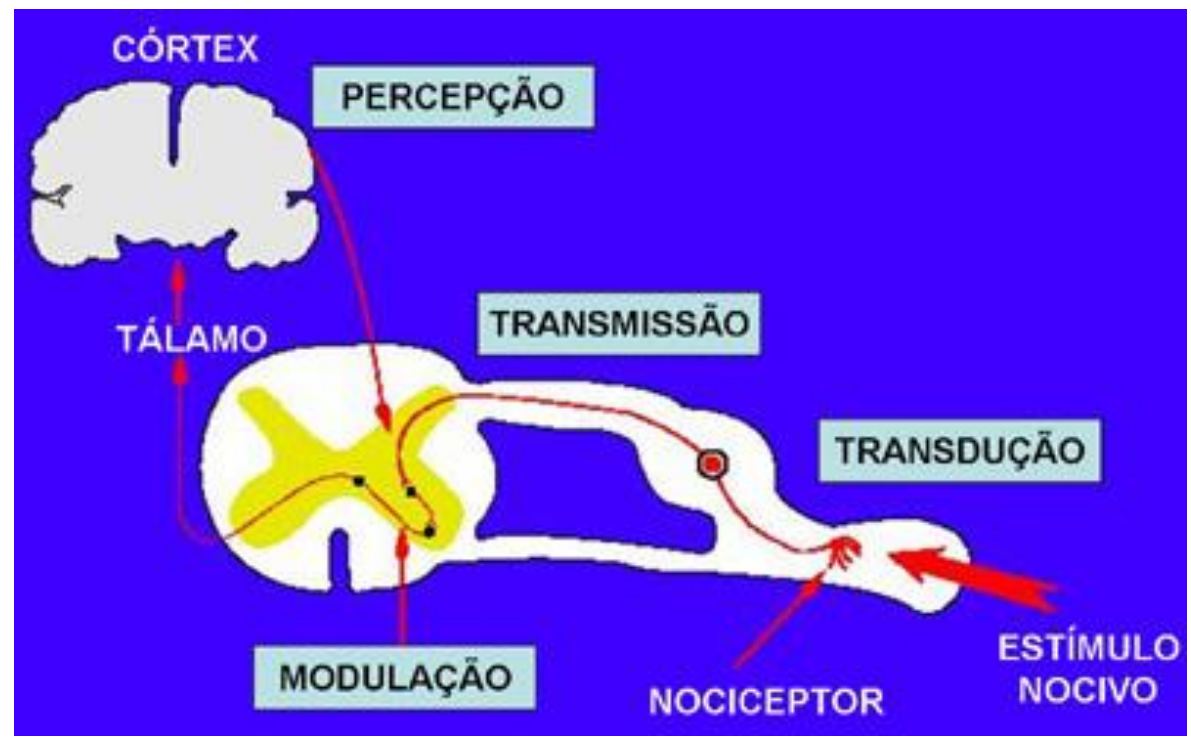

Figura 1: Esquema da Nocicepção - Caminho da Dor (http://www.dol.inf.br/Html/compreendendoDor.htm. Acesso em 15/01/ 2017)l)

O processo da nocicepção é a interpretação de sensações mecânica, térmica e química em impulsos elétricos por terminais nervosos especializados denominados nociceptores. Os nociceptores são terminações nervosas livres dos neurônios de primeira ordem, cuja função é preservar a homeostasia tecidual, assinalando uma injúria potencial ou real (Pisera, 2005).

A avaliação de dor em animais é complexa, pois é influenciada pelo meio ambiente e pelo atividade psíquica, mas como avaliar a dor em animais? Apesar do antropomorfismo não ser a melhor metodologia, dada as grandes diferenças entre as espécies, o princípio da analogia é um bom guia para reconhecer dor em animais, porque a dor e o limiar de dor para estímulos mecânicos, térmicos ou químicos nas diferentes espécies são similares (Luna, 2008).

A manifestação comportamental e corporal mais comum dos animais frente a dor é a vocalização. Para a Etologia Animal, a vocalização e a postura corporal sinalizam estados emocionais dos animais, onde respostas comportamentais e fisiológicas a estímulos nocivos incluem os seguintes sinais: vocalização exacerbada, tentativa de fuga, agressão defensiva, salivação, emissão de urina, de fezes, esvaziamento de glândulas anais, midríase, taquicardia, sudorese, tremores, calafrios e espasmos musculares (Oliveira et al., 2002). 
Reconhecer e quantificar o comportamento doloroso em animais constitui um importante problema a ser solucionado, diante dos diferentes padrões comportamentais exibidos pelas diversas espécies animais. (Almeida et al., 2006). A falta de habilidade em reconhecer a dor em animais dificulta a interpretação de comportamentos que poderiam ser interpretados como reação à dor (Hellebrekers, 2002). Somente nas ultimas três décadas que o conceito de animais sencientes tornou-se tópico de interesse na Biologia, apesar de ser um conceito aceito como conhecimento secular desde a Renascença por homens da ciência como Leonardo da Vinci, Francis Bacon, Thomas More, Shakespeare, Montaigne e Erasmus (Duncan, 2006).

A evolução da ciência e os constantes questionamentos sobre o uso de animais em experimentação científica transformaram o bem-estar animal em uma importante área de estudo (Frajblat et al., 2008) e a partir destes estudos passou-se aceitar que os animais são sencientes (Molento, 2007). Porém, foram poucos os estudos que analisaram a maneira que animais de laboratório expressam a dor (Frajblat et al., 2008).

\subsection{EUTANÁSIA EM ANIMAIS}

Os seres humanos e os animais convivem há milhares de anos e aprenderam a obter vantagens dessa parceria. Durante muito tempo, os animais serviam principalmente de suporte seja ele alimentício ou mecânico como força de tração (animais domésticos). Porém, recentemente, esta relação mudou e permitiu então a separação de animais domésticos e de estimação. Hoje a relação do ser humano com animais de estimação, tornou-se tão complexa que, ao entrar para uma família, ele é capaz de provocar alterações no comportamento de todos os seus membros (Fuchs, 1987).

Com a evolução da medicina e descobertas de agentes infecciosos, o homem também se valeu do animal para melhorar a proteção de sua saúde, surgindo assim a noção de cobaia, que engloba desde pequenos animais (roedores) até primatas de grande porte (Bernard, 1865).

Os princípios do uso de animais como modelo de estudo e transposição para a fisiologia humana foram lançados por Claude Bernard, por volta de 1865. O trabalho "Introdução ao Estudo da Medicina Experimental" procurou 
estabelecer as regras e os princípios para o estudo experimental da medicina. 0 autor provocava situações físicas e químicas que resultavam em alterações nos animais semelhantes a doenças em humanos, e enfatizava então, a aplicabilidade da experimentação animal para uma melhora do bem-estar do homem (Bernard, 1865).

Nos dias de hoje o modelo animal é usado em todos os campos da pesquisa biológica (Russell, 2001). A relação entre os humanos e os animais de outras espécies ganhou contornos mais definidos e a exploração de outras espécies tem regras e uma ética (Vieira \& Hossne, 1998).

Nas últimas décadas, o uso de animais em experimentos e no ensino de técnicas anestésicas e cirúrgicas tem suscitado vários questionamentos que envolvem a possibilidade de sofrimento e a preocupação quanto ao destino a ser dado aos mesmos ao fim dos experimentos (Molento, 2006). A experimentação animal segue um protocolo que exige resultados, para tal finalidade requer eutanásia dos animais para colheita do material que não poderia ser obtido de outra forma, ou porque o animal não pode mais ser utilizado em outro experimento (Oliveira et al., 2002; Molento, 2006).

Existem situações especiais em que a eutanásia é motivada por razões humanitárias, como doenças incuráveis e terminais, em que a morte do animal não é contestada. Situação similar observa-se nos casos em que isso representa a obtenção de alimentos de origem animal. Em ambos os casos, os procedimentos a serem seguidos devem obedecer a critérios que suprimam 0 sofrimento animal (Oliveira et al., 2002).

\subsection{EUTANÁSIA EM ANIMAIS DE CATIVEIRO}

Os animais de cativeiro são animais mantidos em viveiros ou semiliberdade e expostos a visitação pública. Estes servem para atender a finalidades sócio-culturais e objetivos científicos, e se enquadram aqui, aqueles mantidos em Jardins zoológicos e santuários. O Poder Público Federal mantém e autoriza a instalação e o funcionamento de jardins zoológicos (Lei № 7.173, de 14 de dezembro de 1983). Porém esta população segue critérios de controle de 
tamanho populacional e de características genéticas, desencorajando fortemente a consanguinidade.

Segundo a mídia, veterinários de zoológicos no Brasil e no mundo estão de frente a uma escolha entre dois métodos controversos para manter as caracteristicas supracitadas: o controle de natalidade e a eutanásia. Isso acontece porque se deparam com a capacidade de suporte e alocação de animais em recintos limitados e com a pressão para manter coleções diversas e vibrantes de espécies ameaçadas (Fonte: UOL/The New York Time e CFMV).

Nos Estados Unidos, a escolha é a contracepção. Os chimpanzés, as girafas e os ursos pardos são tratados com hormônios contraceptivos por meio da ração ou dispositivos implantados. Até pequenos roedores estão incluídos nesta categoria. Acredita-se que ao prevenir o nascimento de animais além da capacidade de cuidar, pode-se cuidar melhor dos animais que lá estão (The New York Times e Opinião e Notícia).

Já na Europa, alguns veterinários preferem aplicar a eutanásia a filhotes desnecessários depois que eles amadurecem, do que negar aos pais a experiência de procriar e nutrir seus filhotes, permitindo que os animais de cativeiro tenham o comportamento mais natural possível. Desta forma, os zoológicos europeus costumam permitir que os animais cuidem de seus filhotes até uma idade na qual eles naturalmente se separariam dos pais. Com a maturidade dos filhotes os funcionários praticam a eutanásia nos animais que não estão nos planos dos zoológicos (The New York Times e Opinião e Notícia).

As normas éticas internacionais para criação de animais em zoológico têm sido evasivas, em parte porque as filosofias variam. A associação africana de zoológicos lista a eutanásia como uma ferramenta de gerenciamento da população, enquanto os preceitos religiosos dificultam até mesmo a eutanásia de animais terminalmente doentes (The New York Times).

Nos Estados Unidos e na Europa há uma tolerância a eutanásia de felinos e canídeos. A eutanásia é permitida de acordo com as regulações da associação de zoológicos norte-americanos, mas é reservada, sobretudo, para os animais doentes e velhos. Zoológicos europeus que adotam a eutanásia de filhotes saudáveis argumentam que a contracepção oferece riscos para a saúde e tira 
dos animais o rico processo de cuidar dos filhotes - embora matar um animal possa ser às vezes controverso (The New York Times).

A Associação Europeia de Zoológicos e Aquários da Dinamarca aceita esta política e é bastante aberta em relação a educar seu público. A Alemanha, em contraste, permite a eutanásia só em circunstâncias "aceitáveis", o que pode ser difícil de definir, o que gera controvérsias. Por exemplo, há alguns anos no Zoológico de Magdeburg no norte da Alemanha, descobriu-se que um tigre macho era um híbrido entre duas subespécies de tigre. Quando os três filhotes nasceram, o zoológico efetuou a eutanásia, pois justificaram que a prole gerada por híbridos era inúteis para a reposição da espécie (The New York Times e NPR-Why Do European Zoos Kill Healthy Animals?).

\subsection{EUTANÁSIA EM ANIMAIS DOMÉSTICOS}

\subsubsection{Animais domésticos destinados ao abate}

Os animais domésticos destinados ao abate ou de açougue, são animais de pecuária extensiva ou criação própria a alimentar a população humana, e deve ter seu bem-estar garantido desde seu embarque na propriedade rural até o manejo no frigorífico. São considerados animais de açougue mamíferos como bovídeos, equídeos, suínos, ovinos, caprinos, coelhos e aves domésticas bem como os animais silvestres criados em cativeiro, e abatidos (ou eutanasiados) em estabelecimentos sob inspeção veterinária (Normativa $\mathrm{n}^{\circ} 3$, de 17 de janeiro de 2000).

Desde meados da década de 1930, o Brasil, tenta regularizar a obrigatoriedade de atenção ao bem-estar animal. A primeira legislação brasileira que trata desse assunto é o Decreto Lei número 24.645 de julho de 1934.

Por respeito aos animais deve-se garantir que todas as práticas no manejo ocorram com o menor grau de sofrimento possível, e que na cadeia de produção haja preocupação ética, social e ambiental como um todo. Sendo assim, antes do abate, deve-se garantir que os animais foram insensibilizados corretamente, para que a morte se dê enquanto estão inconscientes, evitando sofrimento no momento da sangria. (Normativa $\mathrm{n}^{\circ} 3$, de 17 de janeiro de 2000). 
A insensibilização pode ser realizada por dois métodos, o mecânico e o elétrico, o primeiro através de pistola com dardo cativo ou pistola percussiva não penetrativa que provoca um golpe no crânio causando a inconsciência; o segundo utiliza eletrodos que provocam uma corrente elétrica no cérebro, o que também causa inconsciência. $O$ animal após a insensibilização se encontra

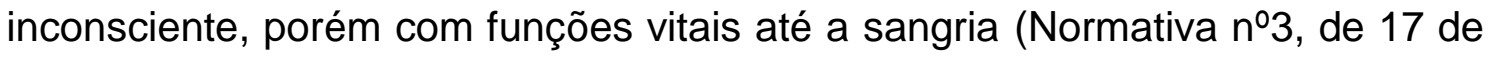
janeiro de 2000).

A operação de sangria deve ser iniciada logo após a insensibilização do animal, de modo a provocar um rápido, profuso e mais completo possível escoamento do sangue, antes que o animal recupere a sensibilidade (Normativa ํㅜㅇ, de 17 de janeiro de 2000).

\subsubsection{Eutanásia em Animais de estimação}

A urbanização cada vez mais crescente vem excedendo hábitos coletivos entre os indivíduos que, isolados em seus lares, têm constituído fortes laços afetivos com algumas espécies, como é o caso dos cães e gatos, transformandoos em verdadeiros entes familiares (Santana et al., 2004).

Segundo Santana et al. (2004), nem sempre esse relacionamento é ético e ambientalmente correto, observando cotidianamente muitas arbitrariedades praticadas pelo homem que aniquilam a dignidade desses seres geralmente indefesos, ao promover todo tipo de maus tratos e crueldade. E ainda, adestrando-os para se tornarem violentos e, assim, utilizá-los como se fossem armas, quando não os abandona a toda tipo de riscos, transformando-os em vítimas inocentes e vetores de doenças, afetando, inclusive, a saúde pública (Santana et al., 2004).

Santana (2006) alerta que o grande problema da posse de animais de estimação está na falta de planejamento. As pessoas compram animais, pelo mero impulso de consumir, sendo estimulado por comerciantes desejosos de lucros, que os expõem precariamente, em vitrines e gaiolas, para que os consumidores se sintam seduzidos por aquela "mercadoria" ou "objeto descartável". Esta relação de consumo muitas vezes não desperta o vinculo afetivo que deve nortear a relação entre homem e animal de estimação, fazendo com que as pessoas acabem descartando seus "animais de estimação", por 
ficarem desinteressantes depois da empolgação inicial. Este descarte gera uma elevada densidade populacional de animais de companhia errantes, formando contingentes incalculáveis nas ruas das grandes cidades de "animais abandonados", denominados, quando cães, vulgarmente como "vira-latas".

Para solucionar o problema da superpopulação e do abandono são necessárias campanhas de educação que estimulem a posse responsável e a promulgação de instrumentos legais que possam efetivar a proteção à fauna, específicos à posse responsável e reservar a eutanásia somente em casos de animais doentes graves ou, então, muito agressivos (Santana et al., 2004).

Quando, a eutanásia individual é necessária e indicada para cães e gatos e animais de pequeno porte, o método preferencial é o uso de derivados de ácidos barbitúricos. O pentobarbital sódico é referido como uma droga de rápida ação e eficácia (Plumb, 2002). Segundo Agostinho \& Léga (2009) 42\% dos médicos veterinários entrevistados em sua pesquisa usam anestesia geral com tiopental ou propofol associado ao cloreto de potássio para realizarem eutanásia em animais domésticos.

A dose letal utilizada para a eutanásia é cerca de três vezes a utilizada para produzir a anestesia, cerca de $27 \mathrm{mg} / \mathrm{Kg}$ para os cães sem pré-medicação. É alternativamente administrada por via peritoneal em altas doses, quando não for possível a injeção intravenosa em animais muito pequenos. A pré-medicação pode prevenir a excitação do animal, nesse caso pode ser usado o benzodiazepínico como xilazina (Oliveira et al., 2003).

\subsection{EUTANÁSIA EM ANIMAIS DE LABORATÓRIO}

A experimentação animal é necessária para as pesquisas científicas, contribuindo para o desenvolvimento da ciência e da tecnologia (Broom, 1991). Cobaias são utilizadas nos diferentes campos científicos, promovendo ao longo dos anos a descoberta de medidas profiláticas e tratamentos de inúmeras enfermidades que acometem os seres vivos. Como exemplos podem citar a descoberta da insulina, o desenvolvimento das vacinas e produção de soros dentre muitos outros (Fagundes e Taha, 2004). O uso dos animais em pesquisa levou os cientistas a descobertas que nos permitiram fazer uso terapêutico de 
antibióticos e tratamentos de diversas doenças. Também foi possível a execução de transplantes de órgãos e uso de fármacos anestésicos (Chorilli et al., 2007).

Animais de várias espécies têm sido utilizados como cobaias sendo os camundongos os mais utilizados e os mais conhecidos cientificamente (Chorilli et al., 2007). Os camundongos acompanham o homem há milênios, e compartilham desde então com humanos suas casas, seus alimentos e suas enfermidades. Disseminaram-se da Ásia para Europa e depois para todo mundo, e atualmente habita qualquer lugar que o homem habite (Franco, 2006). Alem disso, os camundongos possuem semelhanças genéticas significativa com os homens, uma vez que $99 \%$ dos genes humanos possuem homólogos em camundongos, o que permite o a investigação, por exemplo, da etiologia e mecanismos envolvidos nas desordens genéticas (Chorilli et al., 2007).

A introdução do camundongo, como animal de laboratório, deve-se principalmente ao fato de ser pequeno, muito prolífero, ter período de gestação curto, ser de fácil domesticação e manutenção. Devido essas particularidades, é hoje o mamífero mais usado na experimentação animal (Johnson et al., 2010).

\subsection{LEGISLAÇÃO - USO DE ANIMAIS EM PESQUISA}

A criação e a utilização de animais em atividades de ensino e pesquisa científica obedecem a critérios estabelecidos na Lei 11.794 de 08 de outubro de 2008. Segundo esta Lei, a criação e a utilização de animais vertebrados em atividades de ensino e pesquisa científica e a utilização em atividades educacionais, em todo o território nacional, fica restrita a estabelecimentos de ensino superior e estabelecimentos de educação profissional técnica de nível médio da área biomédica. São consideradas como atividades de pesquisa científica todas aquelas relacionadas com ciência básica, ciência aplicada, desenvolvimento tecnológico, produção e controle da qualidade de drogas, medicamentos, alimentos, imunobiológicos, instrumentos, ou quaisquer outros testados em animais, conforme definido em regulamento próprio (Lei 11.994/2008).

Na Lei 11.794 IV art 2o prevê morte dos animais por meios humanitários, onde a eutanásia de um animal deve ocorrer em condições que envolvam, segundo as espécies, um mínimo de sofrimento físico e/ou mental. 
No parágrafo $1^{\circ}$ da Normativa $n^{\circ} 13$ do Conselho Nacional de Experimentação Animal (CONCEA, 2015):

- animal será submetido a eutanásia, sob estrita obediência às prescrições pertinentes a cada espécie, conforme as diretrizes do Ministério da Ciência e Tecnologia, sempre que, encerrado o experimento ou em qualquer de suas fases, for tecnicamente recomendado aquele procedimento ou quando ocorrer intenso sofrimento.

Ademais, em biotérios, a eutanásia é empregada para os animais doentes, fora do padrão genético e/ou sanitário, mutilados devido a brigas, com defeitos físicos, em fase final da vida reprodutiva, idosos ou, ainda, quando proliferam em excesso (Andrade et al., 2002).

Os procedimentos de eutanásia foram inicialmente regulamentados pela Resolução do Conselho Federal de Medicina Veterinária (CFMV), ํㅡㄴ 714, de 20 de junho de 2002. Estão contidos nesta resolução 15 artigos que definem os métodos de eutanásia aceitáveis e não aceitáveis. Estes artigos também ressaltam a necessidade de eutanásia quando o bem-estar estiver ameaçado, como forma de eliminar dor e sofrimento dos animais, caso não seja possível obter alívio por analgésicos, sedativos ou outra forma de tratamentos. Além disso, trás a obrigatoriedade da eutanásia quando o animal constitui ameaça à saúde publica ou animal, ou for objeto de ensino ou pesquisa. O $3^{\circ}$ Art. desta resolução define como necessária a presença do médico veterinário para executar os procedimentos de eutanásia. Ainda, é considerada proibida a prática de eutanásia para animais domésticos saudáveis (CFMV, 2002).

A Lei Arouca (Lei 11.794/2008), que regulamentou a experimentação com animais no Brasil, apresenta pontos fundamentais, como a criação do Conselho Nacional de Controle e Experimentação Animal (CONCEA), a obrigatoriedade da criação das Comissões de Ética no Uso de Animais (CEUA), nas instituições que utilizem animais em pesquisa, além da fixação de normas para a criação e uso dos animais (Maia et al., 2006). 
A existência das CEUAs foi aprovada na forma de substitutivo da comissão de Ciência e Tecnologia e contou com a mobilização de membros de diferentes entidades científicas. Participaram a Sociedade Brasileira para o Progresso da Ciência (SPBC), a Academia Brasileira de Ciências, a Federação das Sociedades de Biologia Experimental (FESBE), a Universidade Federal do Rio de Janeiro/UFRJ e a Fundação Oswaldo Cruz/Fiocruz (Paixão, 2004).

Segundo as Normativas do CONCEA (2015), as CEUAs são integradas por: I - médicos veterinários e biólogos; II - docentes e pesquisadores na área específica; III - 1 (um) representante de sociedades protetoras de animais legalmente estabelecidas no País, na forma do Regulamento.

O foco de atuação de uma CEUA é o bem-estar animal, assumindo o papel de dizer se as ações no que se refere ao uso de animais na pesquisa e no ensino estão corretas ou erradas, se são boas ou ruins e coerentes com a necessidade de uso de animal, para tal. Ao mesmo tempo, a CEUA tem a função de analisar, orientar e divulgar as questões relativas ao bem-estar Animal (Rollin, 1999), cumprir e fazer cumprir, no âmbito de suas atribuições, o disposto nesta Lei e nas demais normas aplicáveis à utilização de animais para ensino e pesquisa, especialmente nas resoluções do CONCEA.

É condição indispensável para o credenciamento das instituições que demandam animais em suas atividades de ensino e/ou pesquisa a constituição prévia das CEUAs. As CEUAs têm como objetivo principal a avaliação dos projetos e autorização para sua realização. Para tanto, avalia os propósitos da pesquisa, níveis de dor e estresse nos animais, as condições e procedimentos nos experimentos, além do número de animais usados na pesquisa em questão. São as comissões que buscam assegurar padrões "humanitários" na criação e no trato dos animais assim como assegurar visibilidade pública (Lei 11.794 /2008). 


\subsection{MÉTOdOS DE EUTANÁSIA ACEITAS OU PRECONIZADAS PELA} CEUA

O método de eutanásia de um estudo in vivo é uma importante escolha e deve levar em consideração as diretrizes e orientações preconizadas por Associações Internacionais, como a Associação Americana de Medicina Veterinária (AVMA) - Guidelines of Euthanasia e o Colégio Americano De Medicina Laboratorial Animal (ACLAM) - Task Force on Rodent Euthanasia. De acordo com estas orientações, um método de eutanásia aceitável caracteriza-se por: 1) a rápida perda de consciência; 2) confiabilidade; 3) a segurança do pessoal; 4) irreversibilidade; 5) compatibilidade com os requisitos de estudo; 6) efeito emocional negativo mínimo sobre os observadores; e 7) compatibilidade com subsequente avaliação, exame, ou a utilização de amostra de tecido.

A eutanásia causa a morte por três mecanismos: (1) depressão direta dos neurônios necessários para a função de vida, (2) a hipóxia, e (3) a ruptura física da atividade do cérebro. O processo da eutanásia deve minimizar ou eliminar a dor, ansiedade e sofrimento antes da perda de consciência (AVMA, 2013).

Os métodos utilizados para realização da eutanásia são classificados em métodos físicos e métodos químicos (FIOCRUZ, 1993; AVMA, 2013):

- Métodos físicos: são os que produzem uma morte por uma metodologia física como deslocamento cervical, concussão cerebral, decapitação, exanguinação, tiro por arma de fogo ou eletrocussão. Esses métodos só devem ser empregados quando outros métodos possam invalidar uma determinada informação ou pesquisa, principalmente aquelas relacionadas com os processos bioquímicos do animal.

- Métodos químicos: são as metodologias que utilizam agentes farmacológicos inalantes, como anestésicos ou gases, ou agentes farmacológicos não inalantes, como pentobarbital sódico ou hidrato de cloral. Esses são os métodos de escolha de melhor resolução e mais estéticos, consequentemente, não causam traumas aparentes ao animal e no observador.

Entende-se por métodos recomendados aqueles que produzem consistentemente uma morte humanitária, quando usados como métodos únicos 
de eutanásia. Já os métodos aceitos sob restrição são aqueles que podem não produzir consistentemente uma morte humanitária devido à natureza técnica, por possuírem um maior potencial de erro por parte do executor ou por apresentarem problemas de segurança. Tais métodos devem ser empregados somente diante da total impossibilidade do uso dos métodos recomendados na Resolução n⿳o. 714 de 20 de junho de 2002, do Conselho Federal de Medicina Veterinária CFMV.

A concussão cerebral é um método físico de eutanásia que produz inconsciência resultante de um golpe produzido com objeto contundente na região frontal da cabeça. Tem sido utilizada em ruminantes, como bovinos, caprinos e ovinos, em suínos e coelhos. Quando executada com eficiência, por pessoas treinadas, produz a inconsciência imediata, minimizando o sofrimento dos animais. Pode ser seguida de secção medular na região atlanto-occipital, antes da sangria. É um método que exige ambiente adequado, sem a presença de pessoas simplesmente motivadas pela curiosidade. Geralmente a concussão é praticada quando os métodos químicos interferem nos resultados a serem obtidos (Oliveira et al., 2003).

A decapitação, outro método físico de eutanásia, pode ser usada para eutanasiar os roedores e coelhos pequenos em ambientes de pesquisa. Isso proporciona um meio para recuperar os tecidos e fluidos corporais que não foram contaminados quimicamente. Ele também fornece um meio de obter tecido cerebral anatomicamente intacto para o estudo (Feldman \& Gupta, 1976). Embora tenha sido demonstrado que a atividade elétrica do cérebro persiste durante 13 a 14 segundos após a decapitação, alguns estudos indicam que esta atividade não se relaciona a percepção de dor, e conclui que gera uma perda de consciência rapidamente (Cartner et al. 2007).

Como vantagens, a decapitação parece induzir a rápida perda de consciência, não contamina quimicamente os tecidos e é rapidamente realizada. As desvantagens estão no manuseio e segurança necessária para realizar a decapitação sem causar angustia nos animais. Há o perigo inerente à guilhotina e devem-se tomar precauções para evitar danos pessoais ao executor. A decapitação pode tambem ser visualmente desagradável para o individuo que executa ou observa o método. 
O uso de armas de fogo, em algumas situações emergenciais em que não se dispõe de outros meios, é justificável, principalmente na eutanásia de animais de grande porte quando se apresentam politraumatizados (Oliveira et al., 2003). Tiro é um dos meios aceitáveis de eutanásia para animais selvagens. Isto requer que o operador seja especialista em tiro, utilizando arma de fogo e munição apropriada para determinada espécie. $O$ projétil deve necessariamente atingir 0 cérebro para que a morte ocorra de imediato. Um animal pode ser fatalmente atingido depois de ser física ou quimicamente capturado. Na captura de animal selvagem livre, são utilizados dardos para longas distâncias com auxílio de zarabatana ou rifle (Euthanasia Guidelines, 2008).

Em procedimentos sucessivos, quando se tratar de grupos de animais a serem submetidos à eutanásia ao mesmo tempo, torna-se difícil minimizar as reações desencadeadas por alguns ou todos os animais do grupo. Isso é consequência do estresse generalizado e crescente, com danos para cada um deles, inclusive podendo afetar emocionalmente as pessoas envolvidas (Euthanasia Guidelines, 2008).

Porém, acidentes envolvendo arma de fogo são relativamente frequentes. Atiradores devem sempre assegurar-se da ausência de humanos ou outros animais na proximidade do animal mirado, em respeito ao protocolo de segurança. Os locais indicados para atingir o animal são o pulmão e a região de coração, já que poucas pessoas têm capacidade de atingir um animal na cabeça a uma distância maior que 25 metros, enquanto que, apontando para o coração ou pulmão a probabilidade de êxito é maior. É melhor atirar de numa posicao dorsal para ventral, do que de uma posição lateral, e identificar as vértebras por meio de palpação. A meta é cortar a coluna vertebral e espinha dorsal tão perto do crânio quanto possível para causar decapitação. A arma pode ser encostada ou colocada nas vértebras do pescoço para assegurar a precisão do tiro. Devese evitar mirar a traquéia ou vasos sanguíneos principais, pois só resultaria em sufocamento sem inconsciência (Euthanasia Guidelines, 2008).

O deslocamento cervical tem sido usado há anos como metodologia de eutanásia. Quando realizado por indivíduos bem treinados em animais adequados, é considerado humanitário. No entanto, existem poucos estudos científicos disponíveis para confirmar esta observação. O método tem sido 
utilizado para eutanásia de pequenas aves, aves domesticadas, camundongos, ratos imaturos ( $<200 \mathrm{~g}$ ), e coelhos. Para camundongos e ratos, o polegar e 0 dedo indicador são colocados em ambos os lados do pescoço, na base do crânio ou, em alternativa, uma haste é pressionada na base do crânio. Com a outra mão, a base da cauda ou os membros traseiros são rapidamente puxados, causando a separação das vértebras cervicais a partir do crânio (Hughes, 1976).

Apresenta como vantagens induzir uma rápida perda de consciência, não contaminar quimicamente o tecido e ser rapidamente realizado. Como desvantagens, o deslocamento cervical pode ser esteticamente desagradável para a pessoa que executa ou observador do método, requer domínio das habilidades técnicas para garantir a perda de consciência rapidamente e a sua utilização para a eutanásia é limitada a pequenos animais.

A utilização de $\mathrm{CO}_{2}$ para a eutanásia de pequenos animais de laboratório é admitida sob condições especiais, isso é, quando se dispõe de uma câmara dimensionada e ambiente condizente para evitar a inalação pelas pessoas. Trata-se de um método de baixo custo, relativamente eficaz e dispensa mão de obra especializada (Oliveira et al., 2003). A inalação de $\mathrm{CO}_{2}$ provoca acidose respiratória e produz um estado anestésico reversível por diminuir rapidamente o pH (Anton et al., 1991). A atividade neural é deprimida logo após a inalação de $100 \%$ de $\mathrm{CO}_{2}$. Quando 7,5\% de dióxido de carbono é inalado, aumenta o limiar de dor, e concentrações iguais e superiores a $30 \%$ causam profunda anestesia e a morte com a exposição prolongada (Niel \& Weary, 2006).

Para eutanásia de equinos e de caninos utilizam-se barbitúricos, como o tiopental, para uso em animais pré-medicados com anestésicos como acepromazina ou com xilazina. O tiopental é a droga de escolha para induzir ou para complementar a eutanásia, por sua rápida ação e por não provocar excitação. Ainda, uma vez alcançado o estado de inconsciência, o processo pode ser finalizado pela administração intravenosa de solução saturada de sulfato de magnésio. $O$ tiopental é administrado até a cessação dos batimentos cardíacos. A apnéia, geralmente, antecede a parada cardíaca e não deve ser o parâmetro único a ser considerado (Oliveira et al., 2003). É um barbitúrico de ação rápida, um depressor do sistema nervoso central, utilizado para anestesia e hipnose. É também o método preferido para eutanásia de cães, gatos e outros 
pequenos animais, para os quais é utilizado como injeção letal intraperitoneal (Grier, 1990).

A xilazina e quetamina associadas são agentes dissociativos injetáveis e agonistas dos receptores adrenérgicos que induzem a rápida perda de consciência e, por vezes, relaxamento muscular, antes da cirurgia e outros

procedimentos. Em situações de overdose, esses agentes podem causar a morte; no entanto, doses que consistentemente produzem morte não foram estabelecidas para a maioria das espécies. Em ratos, a injeção de $100 \mathrm{~mL}$ de uma mistura 10:1 de quetamina:xilazina resulta na morte dentro de 3 a 5 segundos após a conclusão da injeção intraperitoneal destes agentes (Schoell et al., 2009).

\subsection{EXPRESSÃO GÊNICA POST-MORTEM}

Com o avanço em técnicas médicas e de imagens, a procura para desenvolver metodologias que forneçam segurança sobre a melhor escolha do tipo de eutanásia tem aumentado. Métodos de observação de comportamento assim como, a avaliação da dor e do estresse ao qual o animal está submetido são parâmetros que o profissional responsável pela eutanásia precisa conhecer para julgar qual dos métodos estaria o mais próximo de causar uma "boa" morte ou uma morte sem sofrimento. Presume-se que os animais submetidos à eutanásia são seres sencientes, portanto, capazes de sentir, interpretar e responder a estímulos dolorosos e ao sofrimento; por isso há a necessidade de estudos que interpretem a resposta fisiológica do animal neste momento, não somente para avaliar parâmetros de dor e agonia, mas no geral, para conhecer molecularmente o que acontece no momento da morte induzida (AVMA, 2013).

Frente a este dilema prático surgiu a proposta ética de Bem-Estar Animal, em que os profissionais das ciências veterinárias em conjunto com governos e ONG's, tem concordado desde a década de sessenta com a implantação de protocolos de medição e controle para obter o dito 'bem-estar' nas áreas de produção e manutenção de animais. Faz-se necessário buscar novas ferramentas que avaliem estes parâmetros e apontem uma metodologia que leve a melhor morte aos animais (Maldonado, 2008). 
Por meio da neurobiologia e da fisiologia animal, podem-se entender os mecanismos comportamentais e fisiológicos que estão por trás da resposta do animal, frente a estímulos causadores de estresse. Porém, ainda que o animal possa comunicar-se (vocalizações, atitudes posturais e faciais, sinais químicos) hoje em dia, existe uma crescente busca para avaliar de maneira mais objetiva, as modificações fisiológicas e moleculares que ocorrem neste momento (Maldonado, 2008).

Acredita-se que o perfil de expressão gênica em resposta ao método de eutanásia pode ser uma ferramenta plausível para caracterizar cada uma das metodologias hoje aceitas pelas Comissões de Ética e gerar um conjunto de dados que facilite a tomada de decisão no que diz respeito ao "melhor" método. $O$ estudo do transcriptoma oferece novas perspectivas de abordagem nesta área, pois através genes expressos pelo tecido analisado pode-se relacionar a resposta fisiológica com a resposta transcricional (Massuda et al., 1999). A técnica de análise em larga escala, conhecida como microarrays, possibilita uma visão global dos padrões de expressão gênica em amostras biológicas, cuja investigação de milhares de genes ocorre de maneira simultânea. Esta tecnologia revoluciou a medicina preditiva, diagnóstica e farmacológica por meio do aumento substancial da capacidade analítica dos processos moleculares (Mocellin \& Rossi, 2007).

\subsection{ANÁLISE DE EXPRESSÃO GÊNICA}

Várias técnicas vêm sendo desenvolvidas para permitir a análise global e/ou pontual da expressão gênica. A capacidade de medir simultaneamente a expressão de milhares de genes é um sistema analítico poderoso, e a disponibilidade de novas tecnologias para esse fim tem fornecido novas estratégias de estudo da resposta gênica (Mitra et al., 2003). As tecnologias para analisar o perfil transcricional permitem a análise de populações de mRNA a partir de células ou tecidos selecionados, produzindo medidas de expressão gênica em larga escala, no entanto cada tecnologia fornece dados com diferentes utilizações e interpretações (Meyers et al., 2004). 
A análise da expressão gênica por microarranjos produziu uma revolução no estudo da expressão, determinando, simultaneamente, os níveis de expressão de milhares de genes (Schena et al., 1995).

A tecnologia de microarrays pode ser utilizada para a determinação de perfis de expressão gênica, ou para o estudo de genômica funcional. Nesse tipo de estudo, a molécula de interesse é o RNA mensageiro (RNAm). Onde se busca identificar variações na expressão de determinados genes que possam ocorrer como respostas biológicas naturais devido à presença de uma patologia, ou alguma outra condição experimental, à qual a amostra em estudo é submetida (Cheung et al., 1999). 


\section{JUSTIFICATIVA}

A questão que aborda a senciência em animais é um tema polêmico entre os filósofos e causa desacordo dentro da comunidade científica. Segundo Webster (2006), "sentimentos são importantes", traçando desta forma o esqueleto da definição de senciência. DeGrazia (1999) defende que animais sencientes são aqueles dotados de qualquer tipo de sentimento ou estado emocional, como dor e medo, por exemplo. Duncan (2006) alterou este conceito definindo sencientes como "capazes de experimentar estados afetivos positivos e negativos". Broom (2006) amplia o conceito de senciência, afirmando que o animal senciente tem capacidade de avaliar as ações dos outros em relação a si próprio e a terceiros, é capaz de recordar algumas de suas ações e avaliar o risco, tem sentimento e tem um determinado grau de consciência. E por fim, Silverman (2008), apresenta uma definição de senciência de que todos os mamíferos são igualmente sensíveis, mas devido a diferenças genéticas, idade, sexo, experiências anteriores entre outras diferenças, eles podem ter ao mesmo estímulo nociceptivo reações diferentes relacionadas à dor.

Atualmente existe grande ceticismo em relação a senciência animal por parte de determinados segmentos científicos. Há críticas ao se considerar as emoções de um animal e, portanto, grupos científicos céticos exigem provas cientificamente irrefutáveis. Porém, não há provas que os animais não sentem. Atingindo direto ao cerne do problema, Bentham, o reformador social Inglês, escreveu "A questão não é, eles podem raciocinar? Nem, eles podem falar? Mas, eles podem sofrer? ". Diante do exposto, é urgente o conhecimento a cerca do sofrimento causado pelos métodos de eutanásia utilizados nos animais.

A eutanásia é recurso utilizado na experimentação animal como protocolo de obtenção de material para pesquisa. Há uma busca por técnicas novas que promovam o bem-estar animal e que reduzam o uso de animais na experimentação. Enquanto essas técnicas não são otimizadas, torna-se necessário utilizar a eutanásia com cautela e especialmente de forma consciente. Visando estudar sobre o bem-estar animal, torna-se pertinente questionar se os animais são sencientes. $O$ bem-estar é um estado mental, que somente existente em seres sencientes (Molento, 2006). 
Poucos estudos atestam a eficácia dos métodos de eutanásia, ou avaliam/comprovam a ausência de sofrimento do animal. O projeto proposto visa fornecer informações que permitam avaliar e comparar as metodologias tradicionalmente utilizadas. 


\section{OBJETIVO}

\subsection{OBJETIVO GERAL}

Avaliar se há diferença no transcriptoma de cérebro de camundongos (Mus musculus) submetidos a diferentes tipos de eutanásia, em especial de genes relacionados a dor.

\subsection{OBJETIVOS ESPECÍFICOS}

i. Comparar a reprodutibilidade dos métodos de eutanásia, câmara de $\mathrm{CO}_{2}$, deslocamento cervical, guilhotina, xilazina/quetamina e tiopental, intra e intergrupos, considerando o tempo de instalação da morte e consumação do óbito (IMCO) e o perfil de expressão gênica;

ii. Comparar o perfil de expressão gênica (trasncriptoma) entre os diferentes tipos de eutanásia;

ii. Avaliar se há genes relacionados com dor em camundongo expressos nos diferentes tipos de eutanásia 


\section{METODOLOGIA}

\subsection{ANIMAIS}

O modelo experimental escolhido para este estudo foi a linhagem C57BL/6J de Mus musculus, também conhecido como B6, B6J, Black 6, C57 Black, é uma linhagem de camundongos que foi desenvolvida em 1921. Esse organismo modelo foi obtido a partir do cruzamento das espécies Mus musculus musculus e Mus musculus domesticus. É uma linhagem amplamente utilizada e foi a primeira a ter seu genoma sequenciado, sendo utilizado como o genoma referência do camundongo. São utilizados em uma grande variedade de áreas, incluindo pesquisa em biologia cardiovascular, biologia do desenvolvimento, diabetes e obesidade, imunologia, neurobiologia, pesquisa neurossensorial, dentre outros e para produção de camundongos transgênicos (Johnson et al., 2010).

Para o experimento foram utilizados um total de 20 fêmeas da linhagem C57BI/6J jovens, saudáveis, com idade de 12 semanas. As matrizes dessa linhagem, desenvolvidas pelo The Jackson Laboratory, foram adquiridas do Biotério de Imunologia da USP.

As matrizes foram alojadas em gaiolas de polipropileno com grade zincada e mantidos em estante refrigerada da Alesco®, no biotério da Universidade Católica de Brasília/UCB a $25^{\circ} \mathrm{C}$. Os animais foram submetidos a ciclo claro/escuro de 12h/12h. As instalações, as condições ambientais, o manejo e os cuidados com os animais seguiram os padrões recomendados pelo Guide for the Care and Use of Laboratory Animals e em conformidade com as leis aplicáveis ao bem-estar animal de uso e cuidado de animais de laboratório (Lei Federal Brasileira № 6.638 de 08 de Maio de 1979).

Após a expansão da colônia, os animais do estudo foram transportados ao Biotério do Instituto de Ciências Biológicas/IB onde passaram por um período de adaptação de 20 dias antes do inicio do experimento. 


\subsection{GRUPOS EXPERIMENTAIS E PREPARAÇÃO DE TECIDO}

Os camundongos foram aleatoriamente divididos em cinco (5) grupos experimentais que correspondem aos cinco tipos de eutanásia estudados. Foram utilizados quatro (4) indivíduos por grupo experimental. A eutanásia de cada animal ocorreu separadamente em uma sala de procedimentos. Cada grupo foi diferenciado segundo a metodologia de eutanásia: câmara de $\mathrm{CO}_{2}$ $\left(\mathrm{CO}_{2}\right)$, deslocamento cervical (DESL), guilhotina (GUI), xilazina/quetamina (XK) e tiopental (TIO).

Os métodos de eutanásia foram executados por profissional treinado e supervisionado por um médico veterinário garantindo que todas as normas e o respeito à conduta relacionada ao ato. $\mathrm{O}$ tempo decorrido para cada óbito foi registrado. Abaixo estão descritos os cinco grupos aqui analisados.

1) Grupo $\mathrm{CO}_{2}$ : a câmara de $\mathrm{CO}_{2}$ recebeu uma pré-carga (40\%) de $\mathrm{CO}_{2}$ por 1 minuto. Cada animal foi colocado na câmara isoladamente e quando o camundongo apresentou sonolência e desequilíbrio, a válvula foi reaberta por mais 60 segundos. $O$ processo de morte foi cronometrado a partir do momento em que a vávula de gás foi fechada, após a constatação visual da imobolidade do animal (parada do cronometro) a câmara de $\mathrm{CO}^{2}$ foi aberta e os sinais vitais checados confirmando a morte. Todos os animais submetidos a esta metodologia tiveram a morte constatada.

2) Grupo Xilazina/Quetamina (XK): cada animal recebeu uma injeção intraperitoneal de xilazina/quetamina na concentração de 1:2 $\mathrm{mL}(0,30 \mathrm{mg} / \mathrm{kg}$ de xilazina e $2 \mathrm{mg} / \mathrm{kg}$ de quetamina). A dose para eutanásia é três vezes a utilizada para produzir anestesia. A inoculação da associação letal de xilazina/quetamina foi realizada após a contenção do animal em posição ventral. O tempo de processo de morte foi cronometrado após a inoculação, e sua parada ocorreu quando constatada a imobilidade total do animal, os sinais vitais checados confirmando a morte. Todos os animais submetidos a esta metodologia tiveram a morte constatada. 
3) Grupo Tiopental (TIO): cada animal recebeu uma injeção intraperitoneal de tiopental, na concentração de $1 \mathrm{~mL}(25 \mathrm{mg} / \mathrm{kg})$. A dose para eutanásia é também três vezes a utilizada para produzir anestesia. A inoculação letal de xilazina/quetamina foi realizada após a contenção do animal em posição ventral. O tempo de processo de morte foi cronometrado após a inoculação, e sua parada ocorreu quando constatada a imobilidade total do animal, os sinais vitais foram checados confirmando a morte. Todos os animais submetidos a esta metodologia tiveram a morte constatada.

4) Grupo Guilhotina (GUI): foi utilizada guilhotina específica para pequenos animais. $\mathrm{O}$ animal foi contido segundo as normas preconizadas no manual de boas práticas no uso de animais de laboratório. $O$ animal teve sua cabeça colocada no lumen da lámina e firmemente contido, após verificação da segurança pessoal a lâmina da guilhotina foi rapidamente fechada e a decapitação ocorreu imediatamente. O tempo de processo de morte foi cronometrado apartir do momento da separação da cabeça do corpo, o cronometro foi parado somente quando os movimentos reflexos causados pela atividade elétrica cessaram. Os sinais vitais foram checados e todos os animais submetidos a esta metodologia tiveram morte constatada.

5) Grupo Deslocamento Cervical: para o grupo deslocamento cervical foi utilizado técnicas preconizadas pelo ICLAS - International Harmonization of Guidelines on Euthanasia e Resolução no.714 de 20 de junho de 2002 do CFMV. Cada animal foi contido e utilizou-se de uma pinça metálico para segurar a cabeça e com a mão direita segurou-se no centro da cauda e foi feita uma força contrária que levou a ruptura do canal medular entre as vertebras cervicais. $O$ tempo de processo de morte foi cronometrado após o procedimento e foi parado quando o animal se apresentou visivelmente imóvel, seus sinais vitais foram checados e a morte de todos os animais submetidos a esta metodologia tiveram morte constatada.

A constatação da morte foi definida como cessação da resposta a estímulos físicos, no caso específico, resposta ao pinçamento na cauda, além de cessação de batimentos cardíacos (sinais vitais). Esta pode ser realizada a 
partir de distintas avaliações, dentre elas a observação clinica do óbito e a mensuração de impulsos elétricos (Close et al, 1996).

\subsection{COLETA DE TECIDO CEREBRAL}

Após a verificação do óbito pelo médico veterinário, foi realizada a retirada do tecido cerebral total, de cada animal. Após a retirada do cérebro foi efetuada uma limpeza do ambiente, desta forma dando seguimento a eutanásia do próximo animal.

Após separar a cabeça do corpo, foi realizado um corte com tesoura estéril na pele que reveste o crânio, que foi retirado por meio de um corte maior até a altura dos olhos do animal, seguido da remoção dos músculos e exposição do crânio. Com uma tesoura de ponta fina, fez-se um pequeno corte na região de inserção da coluna vertebral em direção à sutura dos ossos na parte superior do crânio, tomando cuidado para que nenhuma das pontas da tesoura se aprofundasse e lesionasse o cérebro. A dura-máter foi removida com cuidado com o auxílio de uma tesoura de ponta fina, rompendo-se os nervos e ligamentos (Morais, 2014). O encéfalo foi colocado em tubo falcon estéril, RNAse free e mantido congelado em nitrogênio liquido até a extração de RNA total.

\subsection{EXTRAÇÃO E AVALIAÇÃO DO RNA}

Após congelamento do tecido cerebral com nitrogênio líquido o material foi macerado em cadinho e pistilo até virar pó. O material pulverizado foi aliquotado em triplicata e armazenado em ultrafreezer $-80^{\circ} \mathrm{C}$.

Para a extração de RNA, foi utilizado $30 \mathrm{mg}$ do tecido homogeneizado, e a extracao foi feita com o kit ILLUSTRA RNAspin (GE) seguindo orientação do fabricante, sem nenhuma modificação.

Após extração, a concentração, qualidade e a pureza do RNA foram avaliadas utilizando-se o espectrofotômetro NanoDrop (Nanodrop ${ }^{\mathrm{TM}}$ ND-8000, Thermo Scientific) e o Bioanalyzer (RNA 6000 NanoLabChip kit 2100 Agilent Technologies). Para mensurar a integridade das amostras de RNA foram obtidas as razões $260 / 280,260 / 230 \mathrm{~nm}$ e o RIN (RNA integrity number).

A razão 260/280 informa o grau de contaminação protéica e deve estar próxima de 2, enquanto a razão 260/230 informa a presença de outros 
contaminantes, como fenol, carboidratos e EDTA, devendo estar entre 2 e 2,2. O RIN é a razão entre o RNA das subunidades ribossomais 28S, 18S e 5S e fornece um parametro de integridade do RNA que varia de 1 a 10, onde 1 referese a um RNA degradado e 10 a um RNA íntegro. Aceita-se como um RNA de boa qualidade aquele que apresente um RIN com valor acima de 7 Os valores de RIN e concentração das amostras utilizadas no estudo estão apresentadas na Tabela 1.

Tabela 1: Concentração e RIN das amostras de tecido cerebral utilizadas no atual estudo

\begin{tabular}{|c|c|c|c|c|}
\hline $\mathrm{CO2}$ & CO21 & CO2 2 & CO2 3 & CO2 4 \\
\hline RIN & 10 & 10 & 10 & 10 \\
\hline $\begin{array}{c}\text { Concentração } \\
(n g / \mu l)\end{array}$ & 529,0 & 260,5 & 193,9 & 262,3 \\
\hline $\begin{array}{c}\text { Deslocamento } \\
\text { cervical }\end{array}$ & DESL 1 & DESL 2 & DESL 3 & DESL 4 \\
\hline RIN & 8,4 & 10 & 8,7 & 9,3 \\
\hline $\begin{array}{c}\text { Concentração } \\
(\mathrm{ng} / \mu \mathrm{l})\end{array}$ & 300,0 & 212,3 & 115,9 & 169,7 \\
\hline Guilhotina & GUI 1 & GUI 2 & GUI 3 & GUI 4 \\
\hline RIN & 2,4 & 9,5 & 9,9 & 10 \\
\hline $\begin{array}{c}\text { Concentração } \\
(\mathrm{ng} / \mu \mathrm{l})\end{array}$ & 549,6 & 445,7 & 238,4 & 184,2 \\
\hline Tiopental & TIO 1 & TIO 2 & TIO 3 & TIO 4 \\
\hline RIN & 9,8 & 9,9 & 8,2 & 9,6 \\
\hline $\begin{array}{c}\text { Concentração } \\
(n g / \mu l)\end{array}$ & 177,7 & 310,7 & 270,8 & 299,1 \\
\hline $\begin{array}{c}\text { Xilanina/ } \\
\text { Quetamina }\end{array}$ & $\mathrm{X} / \mathrm{K} 1$ & $\mathrm{X} / \mathrm{K} 2$ & $\mathrm{X} / \mathrm{K} 3$ & $\mathrm{X} / \mathrm{K} 4$ \\
\hline RIN & 10 & 10 & 10 & 10 \\
\hline $\begin{array}{c}\text { Concentração } \\
(\mathrm{ng} / \mu \mathrm{l})\end{array}$ & 269,0 & 144,3 & 308,7 & 308,2 \\
\hline
\end{tabular}




\subsection{ENSAIO DE EXPRESSÃO GÊNICA}

O RNA foi processado para uso no GeneChip® MoGene 2.0 ST Array Affymetrix (Santa Clara, CA, EUA), de acordo com o protocolo do fabricante. Resumidamente, $100 \mathrm{ng}$ de RNA total contendo controles de RNA poli-A (GeneChip $\AA$ WT PLUS Reagent Kit; Affymetrix) foi usado em uma reação de transcrição reversa (de um kit de ciclo de síntese de DNA; Affymetrix) para gerar primeira cadeia de cDNA. A cobertura de genes e transcritos do GeneChip MoGene 2.0 ST Array está descrita na Tabela 2.

Tabela 2: Cobertura de Transcritos do GeneChip MoGene 2.0 st Array (modificado de Affymetrix; acessado em 24/01/2017).

\begin{tabular}{cc}
\hline Cobertura de Transcritos da Matriz & Mouse Gene 2.0 ST Array \\
\hline Total de transcritos RefSeq cobertas & 35.240 \\
RefSeq - transcritos codificadores, anotação estabelecida & 26.191 \\
RefSeq - transcritos não codificadores, anotação & \\
$\quad$ estabelecida & 3.391 \\
RefSeq - transcritos codificadores, anotação provisória & 1.946 \\
RefSeq - transcritos não codificadores, anotação provisória & 3.712 \\
Transcritos de IncRNA & $\sim 2.000$ \\
RefSeq (Entrez) - Contagem de genes & 26.515 \\
\hline
\end{tabular}

${ }^{1}$ Cobertura de transcrição e contagem de genes derivadas do RefSeq acessado em fevereiro de 2012. O número de genes de camundongo está estimado hoje em 36.525 (Ensembl; acessado em 24/01/2017).

Após a síntese da segunda cadeia, o cDNA de cadeia dupla foi utilizado numa reação de transcrição in vitro (IVT) para gerar cRNA marcado com biotina (GeneChip Expression 3'-Amplification Reagents for IVT-Labeling; Affymetrix). Essa etapa foi seguida de quantificação.

A síntese de $2^{\circ}$ Ciclo de ss-cDNA foi realizada utilizando uns dos kits inclusos no kit GeneChip (2nd-Cycle ss-cDNA Master Mix; Affymetrix) e hidrólise do RNA utilizando $4 \mu \mathrm{L}$ de RNase $\mathrm{H}$. Em seguida foi realizada a purificação do $2^{\circ}$ Ciclo de ss-cDNA, determinada a concentração e medida a absorbância a 260nm usando um espectrofotômetro (NanoDrop®). 
Após a determinação da concentração por espectrofotometria, o ss-cDNA foi fragmentado e marcado com Fragmentation and Labeling Master Mix (Affymetrix). A esta etapa seguiu-se com duas incubações em termociclador (conforme instruções do fabricante). Após esta etapa, o ss-cDNA foi aplicado em um chip de hibridização (WT Cartridge Array Hybridization, Affymetrix) e seguido de incubação de 16 horas, lavagem e escaneamento.

\subsection{ANÁLISE DOS DADOS DE EXPRESSÃO GÊNICA EM LARGA} ESCALA

Buscando genes diferencialmente expressos entre os cinco grupos em análise, os grupos foram comparados, par a par utilizando análise de variância não pareada (ANOVA; $p<0,05)$, por oferecer uma abordagem integrada para a normalização, avaliação de níveis de expressão e testes para a expressão diferencial (Churchill, 2004).

Utilizou-se o aparelho GeneChip Scanner 7G para leitura de sinal da hibridização com captura de imagens, operado com o auxílio do software GeneChip Command Console. A qualidade da hibridização foi determinada utilizando o software Expression Console - EX (Affymetrix). Os GeneChips foram escaneados utilizando o Affymetrix GeneChip Scanner 3000, que detectou os valores de intensidade de sinal resultante da hibridização.

Foram utilizadas análises do tipo Gene Level para examinar se há diferença em relação aos genes expressos (transcritos expressos), os quais foram comparados aos dados importados da Net_Affix_Library_files MoGene-2Ostv1. Utilizou-se na hibridização Oligo B2 ( $3 \mathrm{nM})$ como controle de positivo de hibridização, e como auxílio ao software como localizador de "grade" que define a área de cada spot. Os chips foram considerados com qualidade satisfatória somente quando apresentaram o contorno, cantos e nome visíveis, pois estas regiões estão relacionadas a hibridização do Oligo B2. A verificação da qualidade do ensaio foi realizada por controles positivos internos (BioC, BioD e Cre) e os de amplificação por controles externos que correspondem a genes Dap, Lys, Phe e Thr, adicionados durante o preparo das amostras e são utéis para monitorar o processo de amplificação e marcação do RNA mensageiro. Os dados gerados pelo scanner foram analisados utilizando o software Expression 
Console $^{\mathrm{TM}} 1.4$ da Affymetrix para realizar a normalização do dados e gerar arquivos de sumarização de conjuntos de sondas (CHP) a partir de dados de dados de intensidade características (CEL). A normalização visa eliminar o viés técnico, e a sumarização estabiliza os valores pela méda dos valores de intensidade de sinal de cada probe set.

O software EX usa 0 algorítimo Robust Multi-array Average (RMA) visando minimizar a variação entre as amostras de um mesmo grupo calculando os valores de intensidade de sinal para cada probe set. Para tanto se baseia na median polish, considerando apenas os valores de intensidade das sondas PM (Perfect Match). As etapas desta análise são: (1) correção do background, (2) análise logarítmica (conversão em $\log ^{2}$ ), (3) nomalização de quantiles (valores de uma variável que divide uma distribuição de frequências em grupos iguais), onde são classificados os valores de todos os grupos pela sua intensidade de sinal para cada conjunto de sondas e (4) sumarização.

A análise de genes diferencialmente expressos foi realizada utilizando o software Transcriptome Analysis Console (TAC), versão 3.0, da Affymetrix. Para tanto utilizou-se a abordagem de Gene Level Differential Expression Analysis e o teste ANOVA (Análise de Variância), com significância estatística para $p<0,05$ e FDR (False Discovery Rate) de $5 \%$. As diferenças de expressão foram avaliadas por meio de análises comparativas e pareadas entre grupos desejados, sendo considerado valores de FC $\leq-2$ e $\geq 2$.

Adicionalmente os dados normalizados e sumarizados pelo EX foram analisados pela plataforma LIMMA. Esta plataforma é um pacote para a análise de dados de expressâo gênica advindos de análises de microarrays ou RNA seq. Este pacote foi desenvolvido para trabalhar no ambiente R (Ritchie et al., 2015).

\subsection{ASPECTOS ÉTICOS}

Este estudo foi aprovado pela Comissão de Ética Animal, do Instituto de Ciências Biológicas (IB) - UnB (CONCEA), UnBDoc número 132006/2013 (ANEXO D). 


\title{
5. RESULTADOS
}

\author{
5.1 INTERVALO DE TEMPO DECORRIDO ENTRE A \\ INSTALAÇÃO DA MORTE E A CONSUMAÇÃO DO ÓBITO (IMCO)
}

O tempo de IMCO entre os indivíduos de cada grupo experimental está mostrado na Tabela 3. Observa-se que os menores tempos de IMCO, foram como já esperados, pelos métodos físicos, guilhotina e deslocamento, e o maior com as drogas. A asfixia por $\mathrm{CO}_{2}$ apresentou um tempo intermediário. O maior desvio padrão para tempo de morte foi no grupo xilazina/quetamina, seguido do tiopental, isso é, esses são os grupos com maior variação interindividual e intragrupo.

Tabela 3: Tempo de IMCO entre os indivíduos de cada grupo experimental em segundos.

\begin{tabular}{|c|c|c|c|c|c|c|}
\hline \multirow[b]{2}{*}{ Eutanásia } & \multicolumn{4}{|c|}{ Tempo de IMCO (segundos) } & \multirow[t]{2}{*}{ Média } & \multirow[t]{2}{*}{$\mathrm{DP}( \pm)$} \\
\hline & 1 & 2 & 3 & 4 & & \\
\hline Deslocamento cervical & 25 & 23 & 30 & 26 & 26,00 & 2,94 \\
\hline $\mathrm{CO}_{2}$ & 51 & 49 & 45 & 52 & 49,25 & 3,10 \\
\hline Guilhotina & 5 & 4 & 7 & 6 & 5,50 & 1,29 \\
\hline Xilazina/quetamina & 105 & 135 & 80 & 205 & 131,25 & 54,06 \\
\hline Tiopental & 92 & 145 & 120 & 165 & 130,50 & 31,59 \\
\hline
\end{tabular}

\subsection{TRANSCRIPTOMA DE CÉREBRO DE CAMUNDONGO E METODOLOGIAS DE EUTANÁSIA}

Observou-se a expressão diferencial de 4.780 genes, dentre os 35.740 transcritos acessados, considerando os cinco grupos experimentais de eutanásia testadas neste estudo quando se utilizou o software TAC e o algoritmo ANOVA. Observaram-se diferenças entre os cinco tipos de eutanásias. $O$ dendrograma (Figura 2) apresenta o agrupamento das amostras com relação à expressão diferencial dos genes no cérebro dos animais. O heatmap permite a compração entre as amostras. A cor observada para cada gene refere-se à quantidade - expressão aumentada ou reduzida - sendo que quanto mais próximo de vermelho, maior o aumento, e quanto mais próximo de azul, maior a 
redução de expressão. Observa-se que o grupo do deslocamento cervical se posicionou em um agrupamento isolado dos demais, sugerindo um perfil de expressão distinto. As demais amostras se agruparam em um mesmo ramo, que apresenta uma subdivisão em dois ramos, sugerindo um perfil de expressão gênica similar. As amostras do grupo guilhotina apresentaram consistência no agrupamento, sendo que todas se agruparam em um mesmo sub-ramo. Já as amostras do grupo tiopental (amostras 4) ficaram divididas nos dois grandes subgrupos distintos, sugerindo heterogeneidade.

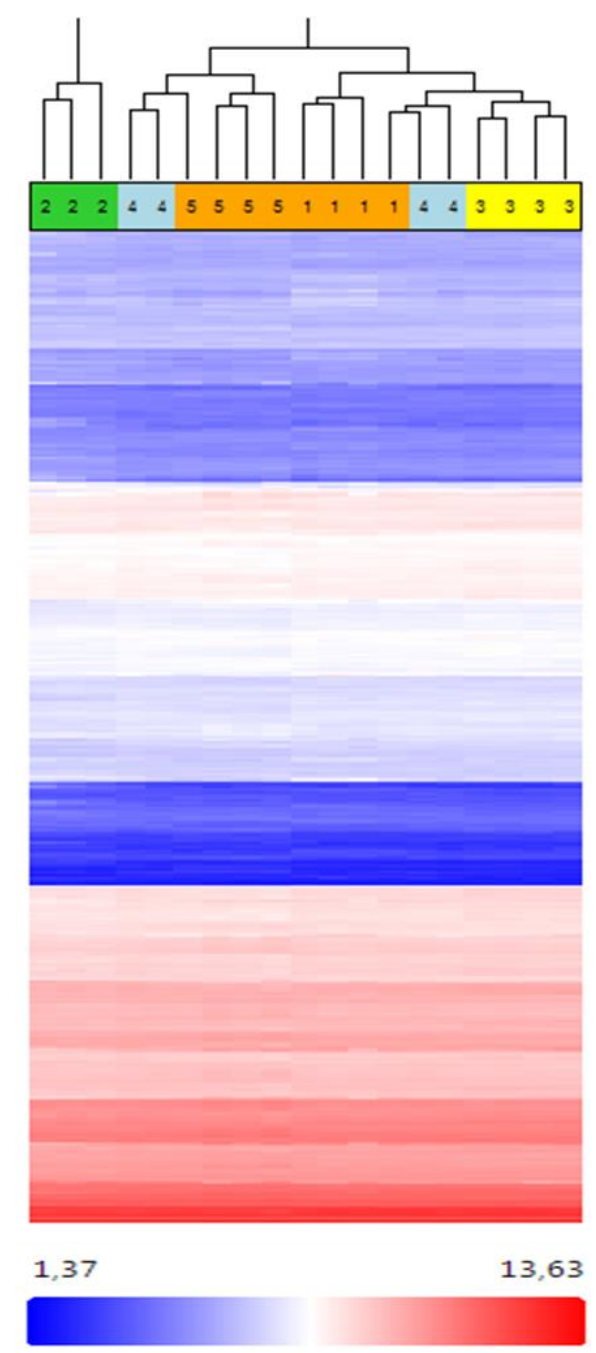

Figura 2: Dendrograma construido a partir dos 4.780 genes diferencialmente expressos entre os cinco grupos de eutanásia (1-CO2; 2-DESL; 3-GUIL; 4-TIO e 5-XK). As diferenças relativas de expressão gênica são proporcionais a intensidade da coloração (heatmap), sendo que azul se refere a diminuição de expressão e vermelho, aumento a expressão 


\subsection{COMPARAÇÃO PAR A PAR DO TRANSCRIPTOMA DE CERÉBRO DE CAMUNDONGO SUBMETIDOS AOS DIFERENTES TIPOS DE EUTANÁSIA}

Os resultados das comparações par a par entre os cinco diferentes grupos mostraram diferenças. Na Figura 3 está apresentado o número de genes diferencialmente expressos quando um tipo de eutanásia é contrastado com outro. O menor número de genes diferencialmente expresso foi para a compração tiopental e guilhotina, enquanto que o maior número observado foi comparando-se a eutanásia por guilhotina com a deslocamento cervical.

A Tabela 4 mostra os genes de dor, assim classificados de acordo com o banco de dados PAINGENESdb, que apresentaram diferença estatisticamente significativa, isso é, quatro genes. Quando os dados de expressão gênica foram comparados considerando o grupo $\mathrm{CO}_{2}$ e deslocamento cervical, os genes Gfra2 e Grasp apresentaram expressão aumentada no grupo $\mathrm{CO}_{2}$. O grupo guilhotina apresentou os genes Gfra2, Grasp e Stoml3 com expressão aumentada em relação ao grupo deslocamento. Já o grupo XK apresentou os quatro genes Gfra2, Glra2, Grasp e Stoml3 com expressão aumentada em relação ao grupo deslocamento.

Dos genes diferencialmente expressos, um total de 65 corresponde a genes vinculados ao processo da dor (Tabela 5). A expressão desses genes foi observada em todos os grupos estudados, sendo que nenhum deles tem sua expressão considerada constitutiva pela literatura. 


\begin{tabular}{|c|cccc|}
\hline Grupo & CO2 & DESL & GUI & TIO \\
\hline DESL & 392 & & \\
GUI & 114 & 416 & 33 & \\
TIO & 115 & 296 & & \\
XK & 249 & 375 & 101 \\
\hline
\end{tabular}

Figura 3: Número de genes expressos diferencialmente considerando a comparação para a par entre os diferentes grupos experimentais.

Tabela 4: Comparação dos grupos de eutanásia com relação a expressão de transcritos de genes de dor $(p<0,05$ e Fold Change Linear $<1,5$ ou Fold Change $>-1,5)$

\begin{tabular}{|c|c|c|c|c|}
\hline \multirow{2}{*}{$\begin{array}{c}\text { Comparação entre } \\
\text { Grupos }\end{array}$} & \multicolumn{4}{|c|}{ Genes de Dor } \\
\hline & Gfra2 & Glra2 & Grasp & Stoml3 \\
\hline $\begin{array}{l}\text { CO2vsDESL } \\
\text { (FC) }\end{array}$ & 2,40 & - & 2,01 & - \\
\hline $\begin{array}{l}\text { GUILvsDESL } \\
\quad(F C)\end{array}$ & 2,32 & - & 2,32 & 2,45 \\
\hline $\begin{array}{l}\text { XKvsDESL } \\
\text { (FC) }\end{array}$ & 2,57 & 2,14 & 2,01 & 2,49 \\
\hline
\end{tabular}

Xilazina/Quetamina. 
Tabela 5: Genes de dor diferencialmente expressos nas condições de eutanásia testadas.

As informações constantes na tabela foram retiradas do banco de dados PAINGENESdb

\begin{tabular}{|c|c|c|c|c|}
\hline Genes & Proteína & Processo Celular & Função & Subfunção \\
\hline Ache & Acetilcolinesterase & Metabolismo & Neurotransmissor & Acetilcolina \\
\hline Adamts5 & $\begin{array}{l}\text { Desintegrina Ligada e } \\
\text { Metalopeptidase } \\
\text { (Reprolisina) com } \\
\text { Trombonspondina Tipo } \\
1 \text { motif, } 5\end{array}$ & Estrutura Celular & $\begin{array}{c}\text { Matrix } \\
\text { Extracelular }\end{array}$ & $\begin{array}{l}\text { Degradação de } \\
\text { Proteínas }\end{array}$ \\
\hline Adora1 & Receptor adenosina $\mathrm{A} 1$ & Sinal Celular & $\begin{array}{l}\text { Receptor de } \\
\text { G-Proteína }\end{array}$ & $\begin{array}{l}\text { Neuromodula- } \\
\text { dor }\end{array}$ \\
\hline Adra1d & $\begin{array}{l}\text { Receptor adrenérgico, } \\
\text { alpha } 1 \mathrm{~d}\end{array}$ & Sinal Celular & $\begin{array}{l}\text { Receptor de G- } \\
\text { Proteína }\end{array}$ & Monoamina \\
\hline Adra2a & $\begin{array}{c}\text { Receptor adrenérgico, } \\
\text { alpha } 2 \underline{a} \\
\text { Proteína }\end{array}$ & Sinal Celular & $\begin{array}{l}\text { Receptor de G- } \\
\text { Proteína }\end{array}$ & Monoamina \\
\hline Camk2a & $\begin{array}{c}\text { calcio/calmodulinadep } \\
\text { endente quinase II } \\
\text { alpha }\end{array}$ & Sinal Celular & $\begin{array}{l}\text { Sinal de tradução } \\
\text { intracelular }\end{array}$ & Quinase \\
\hline Cckbr & $\begin{array}{c}\text { Receptor } \\
\text { colecistoquinina B }\end{array}$ & Sinal Celular & $\begin{array}{l}\text { Receptor de G- } \\
\text { Proteína }\end{array}$ & $\begin{array}{l}\text { Neuromudula- } \\
\text { dor }\end{array}$ \\
\hline $\mathrm{CCr} 7$ & $\begin{array}{l}\text { Receptor quimioquina } \\
\text { (C-C motif) } 7\end{array}$ & Sinal Celular & $\begin{array}{l}\text { Receptor de G- } \\
\text { Proteína }\end{array}$ & Citocina \\
\hline Chrm2 & $\begin{array}{c}\text { Receptor cardíaco } \\
\text { Colinérgico, } \\
\text { muscarínico } 2\end{array}$ & Sinal Celular & $\begin{array}{l}\text { Receptor de G- } \\
\text { Proteína }\end{array}$ & Acetilcolina \\
\hline Chrna4 & $\begin{array}{c}\text { Receptor Polipeptídico } \\
\text { Colinérgico, nicotínico, } \\
\text { alfa } 4\end{array}$ & Sinal Celular & $\begin{array}{l}\text { Ligand-gated } \\
\text { receptor }\end{array}$ & Acetilcolina \\
\hline Chma7 & $\begin{array}{c}\text { Receptor polipeptídico } \\
\text { Colinérgico, nicotínico, } \\
\text { alfa } 7\end{array}$ & Sinal Celular & $\begin{array}{l}\text { Ligand-gated } \\
\text { receptor }\end{array}$ & Acetilcolina \\
\hline Crip2 & $\begin{array}{l}\text { Proteína rica em } \\
\text { Cisteína } 2\end{array}$ & Sinal Celular & $\begin{array}{l}\text { Sinal de tradução } \\
\text { intracelular }\end{array}$ & \\
\hline Ctsb & Catepsina B & Sinal Celular & $\begin{array}{l}\text { Neurotransmitter } \\
\text { Metabolismo }\end{array}$ & Citocina \\
\hline Ctss & Catepsina S & Sinal Celular & $\begin{array}{l}\text { Neurotransmitter } \\
\text { Metabolismo }\end{array}$ & Cytokine \\
\hline Dab1 & Homólogo deficiente 1 & Sinal Celular & $\begin{array}{l}\text { Sinal de tradução } \\
\text { intracelular }\end{array}$ & Protein kinase \\
\hline Disc1 & $\begin{array}{l}\text { Esquizofrenia } \\
\text { pertubada } 1\end{array}$ & Estrutura Celular & $\begin{array}{l}\text { Intracellular } \\
\text { trafficking }\end{array}$ & Development \\
\hline Dlg4 & $\begin{array}{l}\text { Grandes Discos } \\
\text { homologos } 4 \\
\text { (Drosophila) }\end{array}$ & Sinal Celular & $\begin{array}{l}\text { Synaptic } \\
\text { scaffolding }\end{array}$ & \\
\hline Ednra & $\begin{array}{c}\text { Receptor de } \\
\text { Endotelina tipo A }\end{array}$ & Sinal Celular & $\begin{array}{l}\text { Receptor de G- } \\
\text { Proteína }\end{array}$ & $\begin{array}{l}\text { Neuromudula- } \\
\text { dor }\end{array}$ \\
\hline Egr1 & $\begin{array}{c}\text { Resposta de } \\
\text { crescimento rápido } 1\end{array}$ & Regulação Gênica & $\begin{array}{l}\text { Regulação } \\
\text { Transcricional }\end{array}$ & Gene Precoce \\
\hline Gabrg2 & $\begin{array}{l}\text { Receptor GABA-A, } \\
\text { subunidade gama } 2\end{array}$ & Sinal Celular & $\begin{array}{l}\text { Ligand-gated } \\
\text { receptor }\end{array}$ & GABA \\
\hline Gfra2 & $\begin{array}{l}\text { Receptor Neurotrófico } \\
\text { de células gliais } \\
\text { derivadas alpha } 2\end{array}$ & Sinal Celular & $\begin{array}{l}\text { Receptor de } \\
\text { Tirosinaquinase }\end{array}$ & Neurotrofina \\
\hline Gja1 & $\begin{array}{l}\text { Proteína de Ligação } \\
\text { gap, alpha } 1\end{array}$ & Sinal Celular & Proteína de junção & \\
\hline
\end{tabular}




\begin{tabular}{|c|c|c|c|c|}
\hline Glra2 & $\begin{array}{l}\text { Receptor de Glicina, } \\
\text { subunidade alpha } 2\end{array}$ & Sinal Celular & Neurotransmissor & \\
\hline Glra3 & $\begin{array}{l}\text { Receptor de Glicina } \\
\text { subunidade alpha } 3\end{array}$ & Sinal Celular & Neurotransmissor & \\
\hline Gnao1 & $\begin{array}{c}\text { guanina nucleotideo } \\
\text { binding }\end{array}$ & Sinal Celular & $\begin{array}{l}\text { Sinal de tradução } \\
\text { intracelular }\end{array}$ & $\begin{array}{l}\text { Acoplado a } \\
\text { proteína G }\end{array}$ \\
\hline Gnaq & $\begin{array}{c}\text { guanina nucleotideo } \\
\text { binding protein, alpha } \\
\text { q }\end{array}$ & Sinal Celular & $\begin{array}{l}\text { Sinal de tradução } \\
\text { intracelular }\end{array}$ & $\begin{array}{l}\text { Acoplado a } \\
\text { proteína G }\end{array}$ \\
\hline Gnaz & $\begin{array}{c}\text { guanina nucleotideo } \\
\text { binding protein, alpha } \\
\text { z }\end{array}$ & Sinal Celular & $\begin{array}{l}\text { Sinal de tradução } \\
\text { intracelular }\end{array}$ & $\begin{array}{l}\text { Acoplado a } \\
\text { proteína G }\end{array}$ \\
\hline Grasp & $\begin{array}{c}\text { GRP1 (general } \\
\text { receptor for } \\
\text { phosphoinositides 1)- } \\
\text { associated scaffold } \\
\text { protein }\end{array}$ & Estrutura Celular & $\begin{array}{l}\text { Synaptic } \\
\text { scaffolding }\end{array}$ & Glutamato \\
\hline Grin1 & $\begin{array}{c}\text { Receptor de } \\
\text { glutamato, ionotropic, } \\
\text { NMDA1 (zeta 1) }\end{array}$ & Sinal Celular & $\begin{array}{l}\text { Ligand-gated } \\
\text { receptor }\end{array}$ & Glutamato \\
\hline Grm2 & $\begin{array}{l}\text { Receptor de } \\
\text { glutamato, } \\
\text { metabotropic } 2\end{array}$ & Sinal Celular & $\begin{array}{l}\text { Sinal de tradução } \\
\text { intracelular }\end{array}$ & $\begin{array}{l}\text { Acoplado a } \\
\text { proteína G }\end{array}$ \\
\hline Hrh3 & $\begin{array}{l}\text { Receptor de histamina } \\
\text { H3 }\end{array}$ & Sinal Celular & $\begin{array}{l}\text { Receptor de G- } \\
\text { Proteína }\end{array}$ & $\begin{array}{l}\text { Neuromudula- } \\
\text { dor }\end{array}$ \\
\hline Ica1 & $\begin{array}{c}\text { islet cell autoantigeno } \\
1\end{array}$ & Sinal Celular & $\begin{array}{l}\text { Intracellular } \\
\text { trafficking }\end{array}$ & \\
\hline II1rl1 & $\begin{array}{c}\text { interleukin } 1 \text { receptor- } \\
\text { like } 1\end{array}$ & Sinal Celular & $\begin{array}{l}\text { Peptide signaling } \\
\text { molecule }\end{array}$ & Citocina \\
\hline $116 s t$ & $\begin{array}{c}\text { interleukin } 6 \text { signal } \\
\text { transducer }\end{array}$ & Sinal Celular & $\begin{array}{l}\text { Receptor de } \\
\text { Citocina }\end{array}$ & Citocina \\
\hline Irf8 & $\begin{array}{l}\text { interferon regulatory } \\
\text { factor } 8\end{array}$ & Sinal Celular & $\begin{array}{c}\text { Regulação } \\
\text { Transcricional }\end{array}$ & \\
\hline Kcnip3 & $\begin{array}{l}\text { Kv channel interacting } \\
\text { protein } 3 \text {, calsenilin }\end{array}$ & Sinal Celular & $\begin{array}{l}\text { Sinal de tradução } \\
\text { Intracelular }\end{array}$ & $\begin{array}{l}\text { Canal de } \\
\text { Potássio }\end{array}$ \\
\hline Kcnj3 & $\begin{array}{l}\text { potassium inwardly- } \\
\text { rectifying channel, } \\
\text { subfamily J, member } 3\end{array}$ & Sinal Celular & Canal de Íon & $\begin{array}{l}\text { Canal de } \\
\text { Potássio }\end{array}$ \\
\hline Kcnk3 & $\begin{array}{c}\text { potassium channel, } \\
\text { subfamily K, member } 3\end{array}$ & Sinal Celular & Canal de Íon & $\begin{array}{l}\text { Canal de } \\
\text { Potássio }\end{array}$ \\
\hline Kcnt1 & $\begin{array}{l}\text { potassium channel, } \\
\text { subfamily } \mathrm{T} \text {, member } 1\end{array}$ & Sinal Celular & Canal de Íon & $\begin{array}{l}\text { Canal de } \\
\text { Potássio }\end{array}$ \\
\hline L1cam & L1cam & Estrutura Celular & Adesão Celular & \\
\hline Mapk1 & $\begin{array}{l}\text { mitogen-activated } \\
\text { protein kinase } 1\end{array}$ & Sinal Celular & $\begin{array}{l}\text { Sinal de tradução } \\
\text { Intracelular }\end{array}$ & \\
\hline Mapk10 & $\begin{array}{l}\text { mitogen activated } \\
\text { protein kinase } 10\end{array}$ & Sinal Celular & $\begin{array}{l}\text { Sinal de tradução } \\
\text { intracelular }\end{array}$ & \\
\hline Mapk8 & $\begin{array}{l}\text { mitogen activated } \\
\text { protein kinase } 8\end{array}$ & Sinal Celular & $\begin{array}{l}\text { Sinal de tradução } \\
\text { intracelular }\end{array}$ & Quinase \\
\hline Mapt & $\begin{array}{l}\text { Proteína associada ao } \\
\text { microtubulo tau }\end{array}$ & Estrutura Celular & Tráfico Intracelular & Microtubos \\
\hline Mif & $\begin{array}{l}\text { macrophage migration } \\
\text { inhibitory factor }\end{array}$ & Sinal Celular & Pepitídio & Citocina \\
\hline Nav2 & neuron navigator 2 & Sinal Celular & $\begin{array}{l}\text { Sinal de tradução } \\
\text { intracelular }\end{array}$ & \\
\hline Nbl1 & $\begin{array}{l}\text { neuroblastoma, } \\
\text { suppression of } \\
\text { tumorigenicity } 1\end{array}$ & Divisão Celular & Ciclo Celular & \\
\hline Ncam1 & $\begin{array}{l}\text { neural cell adhesion } \\
\text { molecule } 1\end{array}$ & Estrutura Celular & Matrix Extracelular & \\
\hline
\end{tabular}




\begin{tabular}{|c|c|c|c|c|}
\hline $\mathrm{Nfe} 2 \mathrm{I} 2$ & $\begin{array}{l}\text { nuclear factor, } \\
\text { erythroid derived } 2, \\
\text { like } 2\end{array}$ & Regulação Gênica & $\begin{array}{l}\text { Regulação } \\
\text { Transcricional }\end{array}$ & \\
\hline Nlgn2 & neuroligin 2 & Estrutura Celular & Adesão celular & \\
\hline Nppc & $\begin{array}{l}\text { natriuretic peptide } \\
\text { precursor type } C\end{array}$ & Sinal Celular & $\begin{array}{l}\text { Peptide signaling } \\
\text { molecule }\end{array}$ & $\begin{array}{l}\text { Neuromodula- } \\
\text { dor }\end{array}$ \\
\hline Nptx1 & neuronal pentraxin 1 & Estrutura Celular & Sinaptogenesis & \\
\hline Pcsk2 & $\begin{array}{l}\text { proprotein convertase } \\
\text { subtilisin/kexin type } 2\end{array}$ & Metabolismoo & $\begin{array}{l}\text { Modificação de } \\
\text { Proteínas }\end{array}$ & $\begin{array}{l}\text { Neuromudula- } \\
\text { dor }\end{array}$ \\
\hline Per1 & $\begin{array}{l}\text { period homolog } 1 \\
\text { (Drosophila) }\end{array}$ & Sinal Celular & $\begin{array}{l}\text { Regulação } \\
\text { Transcricional }\end{array}$ & Ritmo Circadiano \\
\hline Per2 & $\begin{array}{l}\text { period homolog } 2 \\
\text { (Drosophila) }\end{array}$ & Sinal Celular & $\begin{array}{l}\text { Regulação } \\
\text { Transcricional }\end{array}$ & Ritmo Circadiano \\
\hline Pik3cg & $\begin{array}{l}\text { phosphoinositide-3- } \\
\text { kinase, catalytic, } \\
\text { gamma polypeptide }\end{array}$ & Sinal Celular & $\begin{array}{l}\text { Sinal de tradução } \\
\text { intracelular }\end{array}$ & \\
\hline Pip5k1c & $\begin{array}{l}\text { phosphatidylinositol-4- } \\
\text { phosphate } 5 \text {-kinase, } \\
\text { type } 1 \text { gamma }\end{array}$ & Sinal Celular & $\begin{array}{l}\text { Sinal de tradução } \\
\text { intracelular }\end{array}$ & \\
\hline Plcb1 & $\begin{array}{c}\text { phospholipase C, beta } \\
1\end{array}$ & Sinal Celular & $\begin{array}{l}\text { Sinal de tradução } \\
\text { intracelular }\end{array}$ & \\
\hline Prkaa2 & $\begin{array}{c}\text { protein kinase, AMP- } \\
\text { activated, alpha } 2 \\
\text { catalytic subunit }\end{array}$ & Sinal Celular & $\begin{array}{l}\text { Sinal de tradução } \\
\text { intracelular }\end{array}$ & Quinase \\
\hline Ptgs1 & $\begin{array}{c}\text { prostaglandin- } \\
\text { endoperoxide synthase } \\
1\end{array}$ & Metabolismo & $\begin{array}{l}\text { Metabolismo } \\
\text { Neurotransmissor }\end{array}$ & Prostaglandina \\
\hline Sesn 2 & sestrin 2 & Metabolismo & $\begin{array}{c}\text { Enzima } \\
\text { Mitocondrial }\end{array}$ & \\
\hline & $\begin{array}{l}\text { solute carrier family } 17 \\
\text { (sodium-dependent }\end{array}$ & & & \\
\hline Slc17a7 & $\begin{array}{c}\text { inorganic phosphate } \\
\text { coTransportador), } \\
\text { member } 7\end{array}$ & Sinal Celular & Transportador & \\
\hline Slc6a1 & $\begin{array}{c}\text { solute carrier family } 6 \\
\text { (neurotransmitter } \\
\text { Transportador, GABA), } \\
\text { member } 1\end{array}$ & Sinal Celular & Transportador & \\
\hline Sod2 & $\begin{array}{l}\text { superoxide dismutase } \\
2, \text { mitochondrial }\end{array}$ & Metabolismo & $\begin{array}{c}\text { Enzima } \\
\text { Mitocondrial }\end{array}$ & \\
\hline Stoml3 & $\begin{array}{c}\text { stomatin (Epb7.2)-like } \\
3\end{array}$ & Estrutura Celular & Transportador & \\
\hline
\end{tabular}

\subsubsection{ANÁLISES LIMMA}

Todas as análises feitas utilizando o TAC foram repetidas na plataforma Limma. Os resultados das duas plataformas foram similares, isso é, há uma consistência entre os resultados obtidos nas duas plataformas. Porém, com relação à transcrição de genes relacionados com dor, o número de genes com 
valores estatisticamente significativos aumentou de quatro (Gfra2, Glra2, Stoml3 e Grasp) para sete genes (Kcnip3, Grasp, Gfra2, Dao, Stoml3 e Prl). 


\section{DISCUSSÃO}

Os protocolos de eutanásia utilizados em experimentos laboratoriais levam em consideração parâmetros definidos internacionalmente: rápida perda de consciência, confiabilidade, segurança e efeito emocional negativo mínimo sobre o executor, irreversibilidade e compatibilidade com os requisitos de estudo. Questiona-se, porém, se há correlação entre metodologias de eutanásia mais desagradáveis aos olhos humanos, como o uso da guilhotina e deslocamento cervical, e os que trazem maior benefício ao estudo.

Nesse trabalho foi analisado o transcriptoma de cérebro de camundongos da linhagem C57BL/6J buscando avaliar se há diferença entre cinco tipos de eutanasias preconizados pelas CEUAs. O transcriptoma do tecido de um organismo é uma "fotografia molecular instantânea", que reflete uma resposta a um estímulo externo. Postula-se, apesar do evento final para todos os indivíduos desse estudo ser a morte, que possa ocorrer diferenças no transcriptoma devido a metodologia utilizada para se chegar a esse fim, no caso os diferentes tipos de eutanásia, e que isto estaria refletido no transcriptoma. Essa diferença no transcriptoma pode, potencialmente, ser útil na abordagem de questões fundamentais como reprodutibilidade na metodologia e sofrimento animal. Respostas a esses questionamentos poderiam fornecer subsídios para as tomadas de decisões das CEUAs.

\subsection{INTERVALO DE TEMPO DECORRIDO ENTRE A INSTALAÇÃO DA MORTE E A CONSUMAÇÃO DO ÓBITO (IMCO)}

O primeiro parâmetro analisado nesse trabalho foi o intervalo de tempo decorrido entre a instalação da morte e a consumação do óbito. No presente estudo, os métodos físicos, guilhotina e deslocamento cervical, apresentaram menores IMCO, enquanto as metodologias químicas tiveram maiores e apresentaram maior desvio padrão. A asfixia por $\mathrm{CO}_{2}$ apresentou um IMCO intermediário. Ainda, observou-se nesse trabalho que a estimativa de tempo de morte foi menor com base nos parâmetros utilizados neste estudo do que a encontrada na literatura, estimada com base em impulsos elétricos (CFMV, 2012). 
Os resultados aqui observados com relação as diferenças do IMCO baseado em observação clínica dos sinais vitais entre os grupos experimentais são coerentes e esperadas. Os métodos de eutanásia físicos são rápidos por seccionar fisicamente a medula do cérebro. Já os métodos químicos dependem de um processo de intoxicação em diversos níveis orgânicos, mas contam com sedação e analgesia anterior a intoxicação. $\mathrm{O} \mathrm{CO}_{2}$, por sua vez, induz a inconsciência e posterior asfixia (Raj \& Gregory, 1996; Raj et al., 1997; Dalmau et al., 2010).

O tempo de IMCO com diversas metodologias de eutanásia foi também avaliado tendo como base eletroencefalograma (EEG) e potencial visual evocado (VEP). A utilização dessas técnicas visa avaliar a perda de função cortical durante os 30 primeiros segundos após a aplicação da metodologia de eutanásia (Cartner et al., 2007). Observou-se que animais eutanasiados apresentam uma diminuição rápida na amplitude média do EGG. Considerando a metodologia de deslocamento cervical, essa diminuição ocorreu dentro de 5 a 10 s, de 10 a 15s após administração de $100 \%$ de $\mathrm{CO}_{2}, 15$ a 20 s após decapitação e de 20 a 25s após parada cardíaca provocada por injeção de $\mathrm{KCl}$ intracardíaco (Cartner el al., 2007).

Diferença no IMCO entre animais de um mesmo grupo experimental pode ser decorrente de uma diversidade fisiológica entre os animais e, ainda, pela metodologia utilizada para estimativa do intervalo do óbito. Os camundongos da linhagem C57BL/6J utilizados neste estudo são isogênicos e foram todos oriundos de um mesmo biotério, o que significa que além da similaridade genômica, foram submetidos às mesmas condições ambientais e alimentares. Ainda, todos os animais são provenientes da mesma ninhada, logo têm a mesma idade, apresentam o mesmo sexo (feminino) e peso aproximado. Dessa forma, considera-se que as diferenças fisiológicas sejam ínfimas. Com relação a metodologia utilizada, procurou-se a reprodutibilidade máxima, mas o presente estudo sugere que eutanasia via metodologia física apresenta resultado mais próximos e homogêneos do que as metodologias químicas.

Apesar de termos observado uma homogeneidade em métodos físicos considerando tempo de IMCO, tanto a guilhotina quanto o deslocamento cervical são métodos controversos. O método de deslocamento cervical depende do treinamento e habilidade do executor que tem um alto impacto no sucesso do 
experimento. Considera-se que o que melhor define se o método de deslocamento cervical foi bem executado é o tempo de parada cardiorespiratória. Porém, se o deslocamento cervical for mal executado, o animal pode permanecer vivo e com dor decorrendo, principalmente, de luxação ou lesões na coluna (Carbone et al., 2012). Portanto, essa metodologia se não bem executada não assegura o bem-estar animal.

\subsection{TRANSCRIPTOMA DE CÉREBRO DE CAMUNDONGO E METODOLOGIAS DE EUTANÁSIA}

Considerando os diversos tipos de eutanásia, 4.780 genes apresentaram uma expressão diferenciada e foi suficiente para diferenciar o grupo de animais que foram eutanasiados por deslocamento cervical dos demais. Ainda, os animais eutanasiados por guilhotina apresentam também um perfil de expressão homogêneo, revelado por seu posicionamento no dendrograma. Por outro lado, o heatmap revela que a diferença observada é pequena quando se contrasta, por exemplo, com trabalhos de comparação entre perfis de expressão de tecidos com tumores benignos e malignos (Raposo-Ferreira, 2016).

Considerando pares de grupos experimentais, o par que mostrou a maior diferença com relação ao número de genes diferencialmente expressos foi a guilhotina e deslocamento cervical. Essa observação era inesperada, pois ambos são processos físicos e aparentemente poderiam ser considerados como similares.

Deslocamento cervical e guilhotina são os tipos de morte mais rápidos e com menor variação de tempo de morte entre os indivíduos do grupo. Os métodos físicos apresentam como peculiaridade, em relação aos químicos, a consciência do animal durante $o$ ato e $o$ fato da contenção durante a execução da metodologia. Esta contenção e consciência potencialmente gera stress, o que pode, por sua vez, refletir em diferenças na expressão gênica, incluindo genes que não estejam diretamente ligados a metodologia, mas sim relacionado ao tempo de contenção e a execução da eutanásia. 
Por sua vez, a expressão especifica de genes em resposta a metodologia pode ser uma ferramenta útil pois mostra a ativação de vias metabólicas vinculados a processos distintos.

\subsection{GENES VINCULADOS AO PROCESSO DE DOR E METODOLOGIAS DE EUTANÁSIA}

Dentro dos critérios de bem-estar animal, procura-se evitar o sofrimento do animal sob experimentação, sendo que, inclusive animais moribundos devem ser retirados da experimentação por infringir sofrimento. Buscou-se então nesse trabalho avaliar se há um conjunto de genes que permitisse relacionar a metodologia ao sofrimento. A avaliação dos genes diferencialmente expressos revelou 65 genes dentre os listados como sendo de dor (PAINGENE database), sendo que quatro desses apresentou fold change acima de 2 na comparação para a par entre os diferentes tipos de eutanásia.

Observamos que todos os tipos de eutanásia ativam genes relacionados com a dor, que é conceituada como uma experiência sensorial e emocional desagradável, onde estímulos dolorosos são reconhecidos pelo sistema nervoso relacionados a nocicepção. Sugere-se que o componente emocional se aplica somente a humanos (Klauman et al., 2008). Estabelecer se os animais são sencientes, isso é, apresentam sensibilidade a dor além de estados emocionais, pode permitir definições de melhores práticas experimentais com animais de laboratório. Visto que os mamíferos são sencientes, estes sentem dor (Silverman, 2008). Estudos anatômicos e fisiológicos demonstraram que existem pequenas diferenças nas vias neurais dos mamíferos (Erickson \& Kitchell, 1984), porém a percepção dos estímulos nocivos e a sua condução para o diencéfalo são processos idênticos (Leoffler, 1990).

Há diferença de sensibilidade entre os mamíferos, porém é complexa a confirmação experimental das diferenças a respeito da experiência de dor entre as espécies. A menos que haja prova em contrário, deve-se aceitar que se um procedimento é doloroso ao humano, o mesmo procedimento também é doloroso para os animais (AWA Regulations, 2013). 
No presente estudo, o grupo de eutanásia por $\mathrm{CO}_{2}$ apresentou dois genes de dor com expressão aumentada em relação ao grupo deslocamento. Este é um dos métodos de eutanásia de roedores de laboratório mais utilizado atualmente devido à sua facilidade de uso, disponibilidade, baixo custo e alto nível de segurança do pessoal envolvido (Valentine et al., 2012; Chisholm et al., 2013). Estima-se que 2,5 milhões de roedores são usados em pesquisas biomédicas, anualmente, no Canadá e União Europeia. A maioria destes animais são eutanasiados com dose letal de dióxido de carbono gasoso (Chisholm et al., 2013).

O $\mathrm{CO}_{2}$ estimula receptores da mucosa nasal, o que está associado à sensação dolorosa, sendo esta dependente da concentração de $\mathrm{CO}_{2}$. Tanto humanos como roedores possuem estes receptores na mucosa nasal (Peppel et al., 1993). Evidências a partir de estudos comportamentais apontam que o gás $\mathrm{CO}_{2}$ é aversivo em ratos. Ratas possuem uma estratégia adaptativa de vocalização na faixa ultrassônica, inaudível a seres humanos, que permite a comunicação com membros da mesma espécie durante o processo de exposição ao gás (Wong et al., 2012). A vocalização ultrassônica em roedores reflete um estado negativo, como dor e sofrimento, durante este método de eutanásia (Chisholm et al., 2013).

De acordo com os dados observado para o grupo guilhotina, observou-se aumento de expressão dos genes de dor Gfra2 em comparação ao método de deslocamento. Por outro lado, sugere-se que a injeção peritoneal de xilazina/quetamina seja mais doloroso que o deslocamento cervical, pois observou-se aumento de expressão dos quatro genes de dor: Gfra2, Glra2, Stoml3 e Grasp. O grupo eutanasiado com injeção peritoneal com tiopental não apresentou diferença na expressão de nenhum gene em comparação com os demais grupos.

Os dados aqui apresentados sugerem que o método de eutanásia $\mathrm{CO}_{2}$, guilhotina e xilazina/quetamina apresenta expressão aumentada de genes de dor em relação ao deslocamento cervical. 


\subsection{AVALIAÇÃO IN SILICO DE GENES VINCULADOS AO PROCESSO DE DOR DIFERENCIALMENTE EXPRESSOS}

GFRa2 codifica um receptor que é expresso durante o desenvolvimento embrionário e continua até a idade adulta (Golden et al., 1999). É um nociceptor cutâneo. As fibras $C$ dos neurônios nociceptivos não peptidiérgicos exigem GFRA2 para o prolongamento da fibra e é alvo de inervação cutânea, sendo demonstrado que a deficiência de GFRa2 em camundongos resulta em anormalidades específicas em testes sensoriais (Lindfors et al., 2006; Kupari et al., 2013).

A maior parte das terminações cutâneas nervosas livres não peptidérgicas da almofada da pata do rato requer sinalização GFRa2, sendo este sinal necessário para manter o tamanho dos neurônios sensoriais nociceptivos não mielinizadas correspondentes. Foi proposto que a neurturina, pode atuar como fator de curto alcance auxiliando os terminais de fibra $C$ em sua ramificação, crescimento e permanência da repulsa epidérmica. A neurturina também se distingue por ser requisito trófico, marcador molecular e participa da projeção da coluna vertebral (Lindfors et al., 2006).

O receptor de glicina (Glra2) é composto por duas subunidades, alfa e beta, e atua como um pentâmero. A proteína codificada por este gene é uma subunidade alfa e pode ligar-se a estricnina. Variantes de transcritos que codificam diferentes isoformas foram encontradas para este gene (KallenbornGerhardt et al., 2012). Receptores de glicina (GlyRS) são o tipo predominante de receptor sináptico inibitório presente no cérebro posterior e espinal medula vertebrado São uma superfamília de canais de íons (Miller et al., 2004).

GlyRS são classicamente conhecidos por mediar a transmissão sináptica inibitória entre inter-neurônios e neurônios motores em circuitos reflexos da medula espinhal (Davidoff et al., 1967). Kallenborn-Gerhardt et al. (2012) mostraram que a subunidade GlyRa2 é expressa no corno dorsal da medula espinal dos camundongos. Animais que apresentam diminuição dos níveis de GlyRa2 apresentam comportamento nociceptivo equivalente aos exibidos pelos animais do tipo selvagem em modelos de dor aguda, após injeção de formalina ou CFA em pata posterior, e após a lesão do nervo periférico. Em contraste, a hiperalgesia mecânica induzida por zimosan foi prolongada no Glra2 - / - 
camundongo, em comparação com os do tipo selvagem. Portanto, GlyRa2 contribui seletivamente para sensação de dor inflamatória induzida por zymosan. Ao final do estudo o autor citado e seus colaboradores concluíram que a injeção de zimosan causa uma inflação aguda em camundongos e GlyR $\alpha 2$ tem papel na seletivamente para a resolução da dor inflamatória induzida por zimosan.

No adulto, o GlyRa1 é um heterômero que predomina na medula espinal, e também medeia a neurotransmissão inibitória em vários núcleos do tronco cerebral, bem como nas sinapses definidos no cerebelo e da retina. O GlyRa2 e a3 são subunidades geralmente expressos em níveis mais baixos em comparação com o GlyRa1 e $\beta$ subunidades, e que exibam padrões de expressão sinápticas distintos que são particularmente evidentes na retina (Lynch et al., 2006). A nossa observação de que GlyRa2 é expresso no corno dorsal da medula espinal do rato é consistente com o anterior in situ resultados de hibridação que demonstra a presença de GlyR $\alpha 2$ transcrições no corno dorsal de camundongos.

O GPR1 é uma proteína codificada pelo gene Grasp e é também conhecida como tamalina, uma proteína estruturada composta de múltiplos domínios de interação com proteínas. A tamalina forma um complexo de proteína com o grupo de receptores $1 / 2$ metabotrópicos do glutamato (mGluRs) e fator de troca de nucleotídeos de guanina e citosina promovendo o tráfico intracelular e a expressão de superfície celular do mGluRs grupo 1 em células COS-7 transfetadas e células de neurónios do hipocampo em cultura (Ogawa et al., 2007). Esta proteína também se liga a outras proteinas estruturadas como PSD95, Mint2 e CASK, todas envolvidas na organização pós-sinaptica e tráfico de proteínas.

A deficiência de tamalina resulta na diminuição acentuada na sensibilidade à morfina em respostas agudas e respostas adaptativas prejudicada de morfina e cocaína. A proteína tamalina assim desempenha um papel estrutural crucial na capacidade de resposta às ações tanto de morfina e cocaína (Ogawa et al., 2007).

Mecanoreceptores da pele de camundongos com mutação no gene da proteína stomatin-3 (SLP3, também chamado Stoml3) não respondem a estímulos mecânicos (Weltez et al, 2007). A pele é a maior superfície sensorial 
do organismo, onde a sensação de toque e dor nociceptiva são sentidas primeiro. Os neurônios sensoriais possuem corpos celulares capazes de detectar estímulos e estão localizados nos gânglios da raiz dorsal. Subtipos destes neurônios são especializados para detectar modalidades específicas de estímulos mecânicos. Os canais iônicos mecânico-sensitivos encontrados em muitos neurônios sensoriais não funcionam sem a proteína SLP3. Há uma perda de função em mecano-receptor em camundongos SLP32/2, o que se correlaciona com uma redução na capacidade de discriminação táctil. O comportamento de sensações táteis também é prejudicado em SLP3 mutantes, incluindo dor provocada por lesão neuropática. SLP3 é, portanto, indispensável para a função de um subconjunto de mecano-receptores cutâneos. 


\section{CONCLUSÕES}

1. Os experimentos apresentam alta reprodutibilidade, porém os mais apresentam reprodutibilidade são os físicos, apesar de estes dependerem da boa execução do método.

2. Há diferenças na expressão gênica cerebral post mortem quando se considera diferentes tipos de eutanásia em camundongo, sinalizadas pelos 4.780 genes expressos diferencialmente;

3. 65 genes de dor foram expressos em todos os tipos de eutanásia, porém quatro (Gfra2, Glra2, Grasp e Stoml3) apresentaram expressão diferenciada quando foi realizada uma avaliação par a par;

4. Considerando a reprodutibilidade alcançada com a eutanásia do tipo deslocamento cervical, revelado pelo tempo de IMCO e pela similaridade de perfil de expressão intra grupo, e ainda que se observou baixa expressão dos quatro genes de dor, Gfra2, Glra2, Grasp e Stoml3, esse seria o método de escolha se não fosse o grande problema da execução da metodologia que demanda profissional altamente qualificado.

5. Considerando que a diferença no perfil de expressão evidenciado pelo heatmap é pequena, sugere-se que as metodologias são similares desde que bem executadas. 


\section{REFERÊNCIAS}

Aclam Task Force. PUBLIC STATEMENTS: Report of the ACLAM Task Force on Rodent Euthanasia: 2005.2 Available http://www.aclam.org/content/files/files/public/active/report_rodent_euth.pdf Acessado em agosto de 2014.

Andrade, A., Pinto, S. C., and Oliveira, R. S., orgs. (2002). Animais de Laboratório: criação e experimentação [online]. Rio de Janeiro: Editora FIOCRUZ. 388 p. ISBN: 85-7541-015-6. Available from SciELO Bookshttp://books.scielo.org.

Anton, F., Peppel, P., Euchner, I., et al. (1991). Noxious chemical stimulationresponses of rat trigeminal brain stem neurons to $\mathrm{CO} 2$ pulses applied to the nasal mucosa. Neurosci Lett;123:208-211.

Artwohl, J., Brown, P., Corning, B., \& Stein, S. (2006). Report of the ACLAM task force on rodent euthanasia. Journal of the American Association for Laboratory Animal Science, 45(1), 98-105.

AVMA Guidelines for the Euthanasia of Animals: 2013 Edition. Available at: https://www.avma.org/kb/policies/documents/euthanasia.pdf Acessado em agosto de 2014.

Bernard C. An introduction to the study of experimental medicine (1865). In: Images from the history of medicine division. National Library of Medicine. Disponível em http://www.ihm.nlm.nih.gov.

Carbone, L., Carbone, E. T., Yi, E. M., Bauer, D. B., Lindstrom, K. A., Parker, J. M., ... \& Wilkerson, J. D. (2012). Assessing cervical dislocation as a humane euthanasia method in mice. Journal of the American Association for Laboratory Animal Science, 51(3), 352-356.

Cartner, SC, Barlow SC, Ness TJ. (2007). Loss of cortical function in mice after decapitation, cervical dislocation, potassium chloride injection, and CO2 inhalation. Comp Med;57:570-573. 
Cheung, V.G., Morley, M., Aguilar, F., Massimi, A., Kucherlapti, R., and Childs, G. (1999). Making and reading microarrays. Nature Genet. Suppl. 21, 15-19.

Chisholm, J., De Rantere, D., Fernandez, N. J., Krajacic, A., \& Pang, D. S. (2013). Carbon dioxide, but not isoflurane, elicits ultrasonic vocalizations in female rats. Laboratory animals, 47(4), 324-327.

Chisholm, J., et al. (2013). Carbon dioxide, but not isoflurane, elicits ultrasonic vocalizations in female rats. Laboratory animals 47.4: 324-327.

Chorilli, M., Michelin, D.C., Salgado, H.R.N. (2007). Animais de laboratório: o camundongo. Rev. Ciênc. Farm. Básica Apl., v. 28, n.1, p.11-23.

Chung, Ukhee, et al. (2012). Quantitative analyses of postmortem heat shock protein mRNA profiles in the occipital lobes of human cerebral cortices: Implications in cause of death. Molecules and cells 34.5: 473-480.

Churchill, G. A. (2004). Using ANOVA to analyze microarray data.Biotechniques, 37(2), 173-5.

Close, Bryony, et al. (1996) "Recommendations for euthanasia of experimental animals: Part 1." Laboratory Animals 30.4: 293-316.

Conselho Federal de Medicina Veterinária. Resolução no714, de 20.06.2002. Dispões sobre procedimentos e métodos de eutanásia em animais, e dá outras providências. [Internet]. 2002 [Acessado em 20 ago 2014] Diário Oficial da União (DOU), 21 de junho de 2002. Disponível em URL: http://www.cfmv.org.br/portal/legislacao/resolucoes/resolucao_714.pdf.htm.

da Silva JA, Pinto N.(2011). A dor como um problema psicofísico. Rev. Dor. São Paulo. Apr;12(2):138-51.

Dalmau A, Rodriguez P, Llonch P, et al. (2010). Stunning pigs with different gas mixtures: aversion in pigs. Anim Welf;19:325-333.

Davidoff, R. A., Graham, L. T., Shank, R. P., Werman, R., \& Aprison, M. H. (1967). Changes in amino acid concentrations associated with loss of spinal interneurons. Journal of neurochemistry, 14(10), 1025-1031. 
DeGrazia D, Rowan A. (1991). Pain, suffering, and anxiety in animals and humans. Theoretical Medicine and Bioethics. Sep 1;12(3):193-211.

Duncan, I. J. (2006). The changing concept of animal sentience. Applied Animal Behaviour Science, 100(1), 11-19.

Erickson, H. H., \& Kitchell, R. L. (1984, April). Pain perception and alleviation in animals. In Federation proceedings (Vol. 43, No. 5, pp. 1307-1312).

Fagundes DJ, Taha MO. (2004). Modelo animal de doença: critérios de escolha e espécies de animais de uso corrente. Acta Cir Bras; 19(1): 59-65

Feldman, D. B., Gupta B. N. (1976). Histopathologic changes in laboratory animals resulting from various methods of euthanasia. Lab Anim Sci; 26:218221.

Fiocruz. Fundação Oswaldo Cruz. (1993). Departamento de Biotérios/BioManguinhos. Manual para técnicos em animais de laboratório. Rio de Janeiro: Setor de Multimeios/Fiocruz. 132p.

Fuchs, H. (1987). O animal em casa: um estudo no sentido de desvelar o significado psicológico do animal de estimação. São Paulo: USP. Tese de doutorado (Psicologia experimental). Faculdade de Psicologia.

Golden, J. P., DeMaro, J. A., Osborne, P. A., Milbrandt, J., \& Johnson, E. M. (1999). Expression of neurturin, GDNF, and GDNF family-receptor mRNA in the developing and mature mouse. Experimental neurology, 158(2), 504-528.

GRCm38.p5 (Genome Reference Consortium Mouse Reference 38), INSDC Assembly GCA_000001635.7, Jan 2012. http://www.ensembl.org/Mus_musculus/Info/Annotation

Grier RL, Schaffer CB. (1990). Evaluation of intraperitoneal and intrahepatic administration of a euthanasia agent in animal shelter cats. J Am Vet Med Assoc;197:1611-1615.

Hellebrekers LJ. (2000). Pathophysiology of pain in animals and its consequence for analgesic therapy. Animal Pain. 71-83. 
Holton L, Reid J, Scott EM, Pawson P, Nolan A. (2001). Development of a behaviour-based scale to measure acute pain in dogs. The Veterinary Record. Apr;148(17):525-31.

Hughes, H. C. (2013). Euthanasia of laboratory animals. In: Melby EC, Altman $\mathrm{NH}$, eds. Handbook of laboratory animal science. Vol 3. Cleveland, Ohio: CRC Press, 1976; 553-559.

IACU, Institucional Animal Care and Use Guidebook. (2002). Euthanasia; p. 810; Disponível em: https://grants.nih.gov/grants/olaw/GuideBook.pdf Acessado em 06/06/2016.

Johnson, KR; Yu H; Ding D; Jiang H; Gagnon LH; Salvi RJ. (2010). Separate and combined effects of Sod1 and Cdh23 mutations on age-related hearing loss and cochlear pathology in C57BL/6J mice. Hear Res 268(1-2):85-92.

Kallenborn-Gerhardt, Wiebke, et al. (2012). "Prolonged zymosan-induced inflammatory pain hypersensitivity in mice lacking glycine receptor alpha2." Behavioural brain research 226.1:106-111.

Klaumann, P. R., Wouk, A. F. P. F., \& Sillas, T. (2008). PATOFISIOLOGIA DA DOR (Pathophysiology of pain). Archives of Veterinary Science, 13(1), 1-12.

Kupari, J., Rossi, J., Herzig, K. H., \& Airaksinen, M. S. (2013). Lack of cholinergic innervation in gastric mucosa does not affect gastrin secretion or basal acid output in neurturin receptor GFRa2 deficient mice. The Journal of physiology, 591(8), 2175-2188.

LaCroix-Fralish, M.L., Ledoux, J.B. and Mogil, J.S. (2007). The Pain Genes Database: an interactive web browser of pain-related transgenic knockout studies. Pain, 131:3.e1-3.e4.

Lei 11.794 (BR). Regulamenta o inciso VII, do §1, do art. 225 da Constituição Federal, estabelecendo procedimentos para o uso científico de animais; revoga a Lei no $6.638 / 79$ e dá outras providencias. D.O.U. de 9.10.2008

Lindfors, P. H., Võikar, V., Rossi, J., \& Airaksinen, M. S. (2006). Deficient nonpeptidergic epidermis innervation and reduced inflammatory pain in glial cell line-derived neurotrophic factor family receptor a2 knock-out mice. Journal of Neuroscience, 26(7), 1953-1960. 
Loeffler, K. (1990). Pain and suffering in animals. Berliner und Munchener tierarztliche Wochenschrift, 103(8), 257-261.

Luna SP. (2008). Dor, senciência e bem-estar em animais-senciência e dor. Ciência veterinária nos trópicos. Apr;11:17-21.

Maia, A.S., Porto, A.L.S., Amado, R.C. (2006). Reflexões sobre a aplicabilidade dos princípios bioéticos nas pesquisas com animais. Artigo científico - VIII Curso de Pós-graduação lato sensu em Bioética, Universidade de Brasília/UnB, Brasília.

Maldonado, N. A. C. Reflexões em torno de uma ética animal./ Disponível em < http://www.homeopatiaveterinaria.com.br/Reflexoes_de_uma_etica_animal.htm >. Acesso em: 09/11/2014.

Massuda N, Ohnishi T, Kawamoto S, Monden M,Okubo K. (1999). Analysis of chemical modification of RNA from formalin-fixed samples and optimization of molecular biology applications for such samples. Nucleic Acids Res 27:44364443.

Meyers, B. C.; Galbraith, D. W.; Nelson, T.; Agrawal, V. (2004). Methods for Transcriptional Profiling in Plants. Be Fruitful and Replicate. Plant Physiology, v. 135, p. 637-652.

Miller, P. S., Harvey, R. J., \& Smart, T. G. (2004). Differential agonist sensitivity of glycine receptor a2 subunit splice variants. British journal of pharmacology, 143(1), 19-26.

Mitra, R. D.; Shendure, J.; Olejnik, J.; Edyta, K. O.; Church, G. M. (2003). Fluorescent in situ sequencing on polymerase colonies. Analls of Biochemistry, v.320, p. 55-65.

Mocellin, S., Rossi, C. R. (2007). Principles of gene microarray data analysis. Adv Exp Med Biol; 593:19-30.

Morais, J. A. (2014). Toxicidade aguda e crônica do chá de Ayahuasca (Banisteriopsis caapi e Psychotria viridis), por análise histológica em ratas Wistar. Dissertação de Mestrado, Brasília - DF, pp.87. 
Niel, L., Weary, D. M. (2006). Behavioural responses of rats to gradual-fill carbon dioxide euthanasia and reduced oxygen concentrations. Appl Anim Behav Sci; 100:295-308.

NYTimes - >Disponível em: http://www.nytimes.com/2012/08/03/science/zoosdivide-over-contraception-and-euthanasia-for-animals.html? >Acesso em 17/01/2017.

Ogawa, M., Miyakawa, T., Nakamura, K., Kitano, J., Furushima, K., Kiyonari, H., ... \& Nakanishi, S. (2007). Altered sensitivities to morphine and cocaine in scaffold protein tamalin knockout mice. Proceedings of the National Academy of Sciences, 104(37), 14789-14794.

Oliveira, H. P., Alves, G. E. S., \& Rezende, C. M. D. F. (2003). Eutanásia em Medicina Veterinária. Escola de Medicina Veterinária.

Paixão, R. L. (2004). As Comissões de Ética no Uso de Animais. Revista do Conselho Federal de Medicina Veterinária. v. 10, p. 13-20.

Pazin-Filho A. (2005). Morte: considerações para a prática médica. Medicina (Ribeirao Preto. Online). Mar 30;38(1):20-5.

Peppel, P., \& Anton, F. (1993). Responses of rat medullary dorsal horn neurons following intranasal noxious chemical stimulation: effects of stimulus intensity, duration, and interstimulus interval. Journal of neurophysiology, 70(6), 22602275.

Pessini, L. (2004). EUTANÁSIA: Porque abreviar a vida? Editora do Centro Universitário São Camilo. Edições Loyol.

Petrov P, Francischi JN, Ferreira SH, et al. tradutores. (2011). NOCICEPTORES: As células que sentem dor Ribeirão Preto - SP: Dor On Line; 106 p. Disponivel em: http://www.dol.inf.br/nociceptores

Raj AB, Johnson SP, Wotton SB, et al. (1997). Welfare implications of gas stunning pigs: 3 . the time to loss of somatosensory evoked potentials and spontaneous electrocorticogram of pigs during exposure to gases. Vet $\mathrm{J}$; 153:329-339.

Raj ABM, Gregory NG. (1996). Welfare implications of the gas stunning of pigs:

2. Stress of induction of anaesthesia. Anim Welf; 5:71-78. 
Raposo-Ferreira, T. M., Salvador, R. C., Terra, E. M., Ferreira, J. H., VechettiJunior, I. J., Tinucci-Costa, M., ... \& Laufer-Amorim, R. (2016). Evaluation of vascular endothelial growth factor gene and protein expression in canine metastatic mammary carcinomas. Microscopy Research and Technique, 79(11), 1097-1104.

Regulations, A.W.A. (14). CFR Title, 9, 1-3. 2013

Ritchie, ME, Phipson, B, Wu, D, Hu, Y, Law, CW, Shi,W, Smyth, GK (2015). LIMMA powers differencial expression analysis for RNA sequencing and Microarrays studies Nucleic Acids Research 43 (7) e 47

Rocha, D. (2007). Aumentam casos de eutanásia em animais da fauna selvagem. In:FAUNA BRASIL.08-ago-2007./ Disponível em: <http://www.faunabrasil.com.br/>. Acesso em 24/11/2014.

Rollin, B. E. (1999). An Introduction to Veterinary Medical Ethics: Theory and Cases. 1st edition, lowa University Press.

Russell, B. (2001). História do pensamento ocidental. São Paulo: Ed. Publicações S/A.

Santana, L. R. e Marques, M. R. (2002). Maus tratos ecrueldade contra animais nos Centos de Controle de Zoonoses: aspectos jurídicos e legitimidade ativa do Ministério Público para propor Ação Civil Pública. in BENJAMIN, Antônio Herman V. (org.). Anais do $6^{\circ}$ Congresso Internacional de Direito Ambiental, de 03 a 06 de junho de 2002: 10 anos da ECO-92: O Direito e o Desenvolvimento Sustentável. São Paulo: IMESP.

Schena, M.; Shalon, D.; Davis, R. W.; Brown, P. O. (1995). Quantitative monitoring of gene expression patterns with a complementary DNA microarray. Science, v. 270, p.467-470.

Schoell, A .R., Heyde, B. R., Weir, D.E., et al. (2009). Euthanasia method for mice in rapid time-course pulmonary pharmacokinetic studies. J Am Assoc Lab Anim Sci; 48:506-511.

Silverman J. (2008). Sentience and sensation. Lab animal. Oct 1; 37(10):465. 
University Of Minnesota. Academic Health Center. Euthanasia Guidelines Resfarch Animal Resource. Disponível em: <http://www.ahc.umn.edu/rar/euthanasia.html >. Acesso em 24/11/2014.

UOL Notícias. http://noticias.uol.com.br/ultimas-noticias/efe/2014/11/03/morrenos-eua-jovem-com-cancer-que-planejou-seu-suicidio-assistido.htm

Vieira, S, Hossne, WS. (1998). A ética e a metodologia. São Paulo: Ed Pioneira.

Von Keyserlingk MA, Rushen J, de Passillé AM, Weary DM. (2009). Invited review: The welfare of dairy cattle-Key concepts and the role of science. Journal of Dairy Science. Sep 30;92(9):4101-11.

Wetzel, C., Hu, J., Riethmacher, D., Benckendorff, A., Harder, L., Eilers, A., ... \& Erdmann, B. (2007). A stomatin-domain protein essential for touch sensation in the mouse. Nature, 445(7124), 206-209.

Wong D, Makowska IJ and Weary DM. (2012). Rat aversion to isoflurane versus carbon dioxide. Biol Lett; 9:20121000. 
9. ANEXOS 


\section{ANEXO A - ATESTADO SANITÁRIO PARA EMISSÃO DE GTA DE ANIMAIS DE LABORATÓRIO}

ATESTADO SANITÁRIO PARA A EMISSÃO DE GTA DE ANIMAIS DE LABORATÓRIO

\begin{tabular}{|c|c|c|}
\hline & & ATESTADO N $N^{0} 11 / 2014$ \\
\hline \multicolumn{3}{|c|}{ 1. PROPRIETÁRIO/PESSOA ACOMPANHANTE DO ANIMAL } \\
\hline \multicolumn{3}{|c|}{$\begin{array}{l}\text { Nome Completo } \\
\text { Instituto de Ciências Biomédicas - USP - CNPJ 63.025.530/0005-38 - Insc. Estadual Isento }\end{array}$} \\
\hline \multicolumn{3}{|c|}{$\begin{array}{l}\text { Endereço Completo } \\
\text { Av. Professor Lineu Prestes, } 1730 \text { - Cidade Universitária - Cep 05508-000 }\end{array}$} \\
\hline $\begin{array}{l}\text { Cidade } \\
\text { São Paulo }\end{array}$ & \begin{tabular}{|l} 
Estado \\
Săo Paulo
\end{tabular} & $\begin{array}{l}\text { Telefone } \\
\text { (11) } 3091-0910 \text { e (11) } 3091-7398\end{array}$ \\
\hline
\end{tabular}

2. IDENTIFICAÇÃO DO ANIMAL

Espécie (nome comum e científico)

08 Camundongos - Mus musculus $\quad$ Sexo

(04 fêmeas e 04 machos) Linhagem: C57BL/6 J

Data de nascimento ou idade estimada

11 semanas

$X$ Fêmea $X$ Macho Desconhecido

Identificaçăo do animal (se presente, tatuagem, microchip, brinco)

Pelagem (cor e tipo, se aplicável)

Preta

Localização do microchip, tatuagem ou brinco (se presente)

\section{DESTINATÁRIO/PESSOA ACOMPANHANTE DO ANIMAL}

UnB -Universidade de Brasília ; CNPJ: 00.038.174/0001-43

Endereço de destino:

CAMPUS I QS 07 LT 01 EPCT AGUAS CLARAS TAGUATINGA SUL CEP 71966-700 Brasilia DF

A/C: Vanessa Teixeira

Docente responsável Profa. Dra. Aline Pic-Taylor; RG: 277284612 SSP SP; CPF: $165117658-22$

\begin{tabular}{|l|l|l|l|}
\hline DISTRITO FEDERAL & Estado DF & Telefone
\end{tabular}

4. DECLARAÇÃO DO MÉdICO VETERINÁRIO

Declaro que o(s) animal(s) acima identificado(s) foram por mim examinados e estavam clinicamente sadios, isentos de ectoparasitas à inspeção clínica e aptos a serem transportados. *

Médica Veterinária Emitente

Ana Tada Fonseca Brasil Antiorio

CPF 288.169.688-00

RG. 29.584.502-8 SSPISP

\begin{tabular}{l|l}
\hline CRMV-SP: 15.646 & Local e Data
\end{tabular}

\begin{tabular}{|l|l|}
\hline CRMV-SP: 15.646 & $\begin{array}{l}\text { Local e Data } \\
\text { São Paulo, 23 de julho de } 2014 .\end{array}$ \\
\hline ASSINATURA E CARIMBO & $\begin{array}{c}\text { Ana } \\
\text { Medica Veterinária } \\
\text { CRMV - SP: } 15.646\end{array}$ \\
\hline
\end{tabular}

Este atestado deve ser emitido dentro dos 3 dias anteriores à expedição da Guia de Trânsito Animal. 


\section{ANEXO B - RESULTADOS DOS EXAMES BACTERIOLÓGICOS}

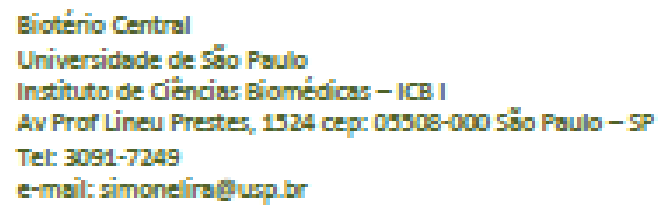

\begin{tabular}{|l|l|}
\hline ORIGEM: Imunologia & PROTOCOLO: 1071 \\
\hline ESPECIE: Mus domesticus domesticus & UNHAGEM: SENT LOTE D \\
\hline Sexo: 2 fêmeas & IDADE: adulto \\
\hline
\end{tabular}

\section{RESULTADO DOS EXAMES BACTERIOLÓGICOS}

Foram coletadas amostras de fezes do jejuno, ceco e intestino grosso, bem como amostras da orofaringe, semeadas em meios seletivos, incubadas por $24-48$ horas a $37^{\circ}$, em aerobiose e anaerobiose. A identificação das bactérias foi feita pelo sistema EPM-MILi (PROBAC), Bactray 1,2 e 3 e BBL Crystal (LABORCUN).

\begin{tabular}{|c|c|c|c|}
\hline MICRORGANISMOS & RESULTADOS & LABORATÓRIO & MÉTODO \\
\hline Citrobacter froundiv & Nesativo & LCSA-ICB & Cultura \\
\hline Posteurnilo pnoumotrogica & Negativo & $\angle C S A-I C B$ & Idem \\
\hline Posteurnilo multocida & Negativo & LCSA-ICB & Idem \\
\hline Saimonella spg & Negativo & $\angle C S A-I C B$ & ldem \\
\hline Streptobocilius moniliformis & Negativo & LCSA-ICB & Exame físico + culturs \\
\hline Streptococcus $\beta$ nemalitico & Negativo & LCSA-ICB & Cultura \\
\hline Streptococcus pnoumoniag & Negativo & $\angle C S A-I C B$ & Idem \\
\hline Stophylococavs aurous & Negativo & LCSA-ICB & idem \\
\hline Providomones aeruginesa & Negativo & LCSA-ICB & Idem \\
\hline Kobsiollig gneumonioe & Nesativo & $\angle C S A-I C B$ & Idem \\
\hline Proteus mirabilis (Intestino) & Nesativo & LCSA-ICB & Idem \\
\hline Protous mirabilis [Pulmäo] & Nesativo & LCSA-ICB & Idem \\
\hline
\end{tabular}

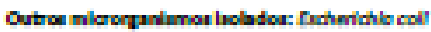

$$
\begin{gathered}
\text { Simone Lira da Cruz } \\
\text { Bióloge } \\
\text { Craio 074172/01-0 }
\end{gathered}
$$




\section{ANEXO C - LAUDO PARASITOLÓGICO DOS ANIMAIS}

UNIVERSIDADE DE SÃO PAULO

Instituto de Ciências Biomédicas

Supervisão Técnica de Biotérios

Fone : (011) 3091-7748 São Paulo - SP.

E-mail: thamar@usp.br

São Paulo, 24 de Abril de 2014

\section{Laudo Parasitológico}

(camundongo, rato e hamster)

Identificação:

\begin{tabular}{|l|l|}
\hline Origem: Biotério de Matriz - ICB - USP \\
\hline Espécie: Camundongo & Linhagem: Balb/c, Balb PAF R, \\
\hline Manejo: Criação & Idade ou Nascimento: 01 a 16/02/14 \\
\hline Número de Amostras: 24 & Sexo: M e F \\
\hline Recebido em: $10 / 03 / 14$ & Examinado em: 14/03/14 \\
\hline Obs:ж C57BI/6 MerCre Mer, C57BI/6J, C57BI/6 Rag, 129Sv GR... \\
\hline
\end{tabular}

Método utilizado:

Exame da pelagem por meio de microscópio entomológico para pesquisa de ectoparasitas

Exame direto microscópico do raspado da mucosa intestinal para pesquisa de endoparasitas

Resultados:

\begin{tabular}{|c|c|}
\hline PARASITAS & RESULTADO \\
\hline Myobia musculis & ---- \\
\hline Myocoptes musculinus & $\overline{c-\cdots}$ \\
\hline Poliplax sp & $\overline{y---}$ \\
\hline Giardia sp & $\begin{array}{ll}-\cdots \\
-\cdots-\end{array}$ \\
\hline Tritrichomonas muris & 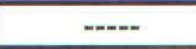 \\
\hline Spironucleus muris & $\begin{array}{l}-\cdots \\
-\cdots-\end{array}$ \\
\hline Hymenolepis nana & $\begin{array}{ll}-\cdots \\
-\cdots-\end{array}$ \\
\hline Hymenolepis diminuta & $\begin{array}{ll}-\cdots \\
-\cdots\end{array}$ \\
\hline Syphacia sp & $\overline{y-\cdots}$ \\
\hline Aspiculuris tetraptera & $\begin{array}{l}---- \\
\end{array}$ \\
\hline Eimeria sp & $\overline{-n-\infty}$ \\
\hline Entamoeba muris & $\begin{array}{ll}-\cdots \\
-\cdots-\end{array}$ \\
\hline Chilomastix Bettencourt & 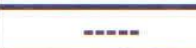 \\
\hline
\end{tabular}

1 a 5 por campo
6 a 10
$>10$
incontáveis

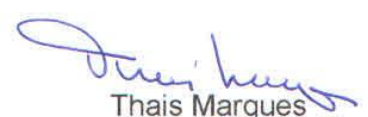

Supervisora Técnica de Biotérios ICB/USP 
ANEXO D - APROVAÇÃO DA COMISSÃO DE ÉTICA NO USO ANIMAL

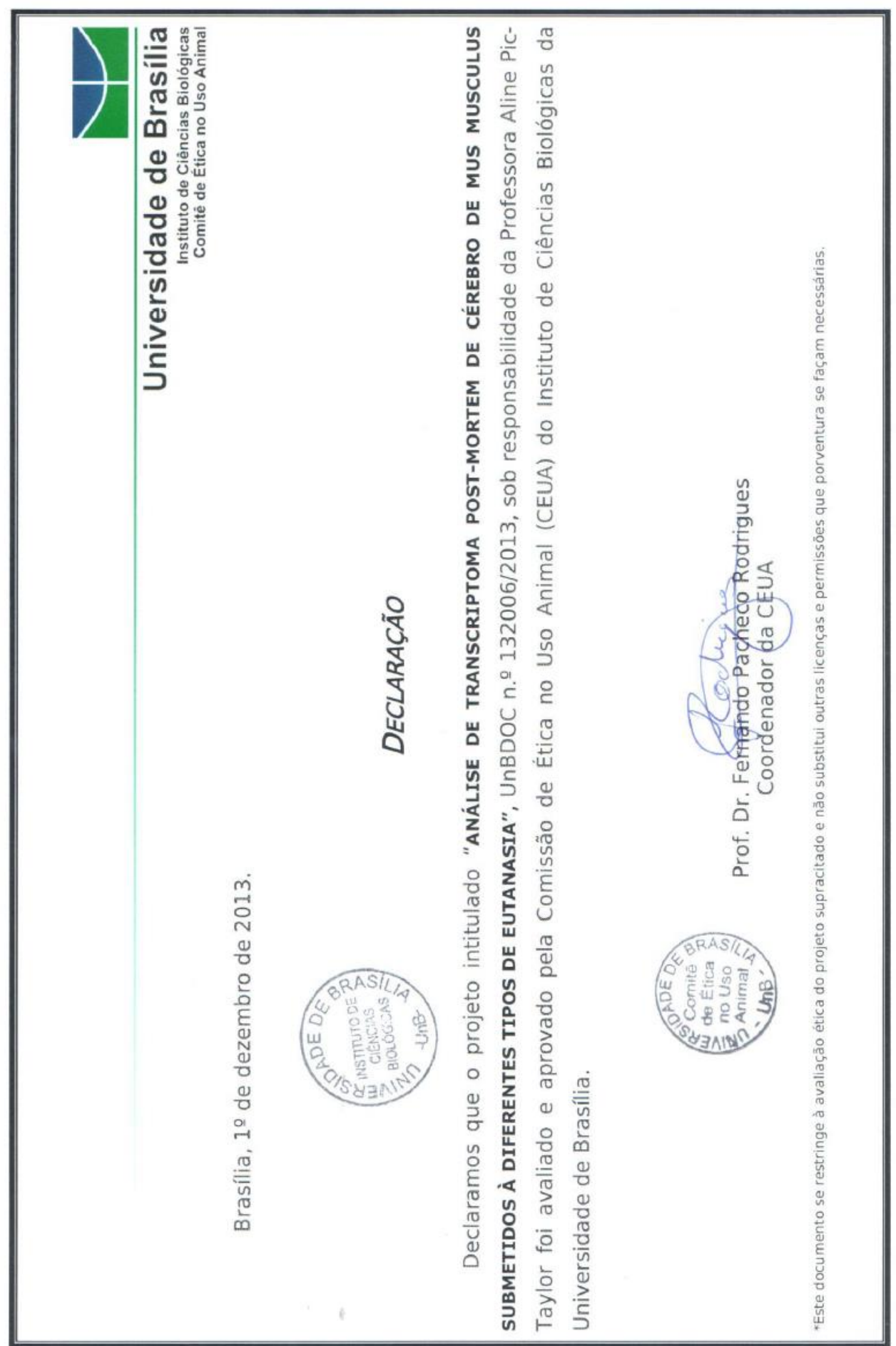

